Prepared in cooperation with the Texas Commission on Environmental Quality

\title{
Automated Delineation and Characterization of Watersheds for more than 3,000 Surface-Water-Quality Monitoring Stations Active in 2010 in Texas
}

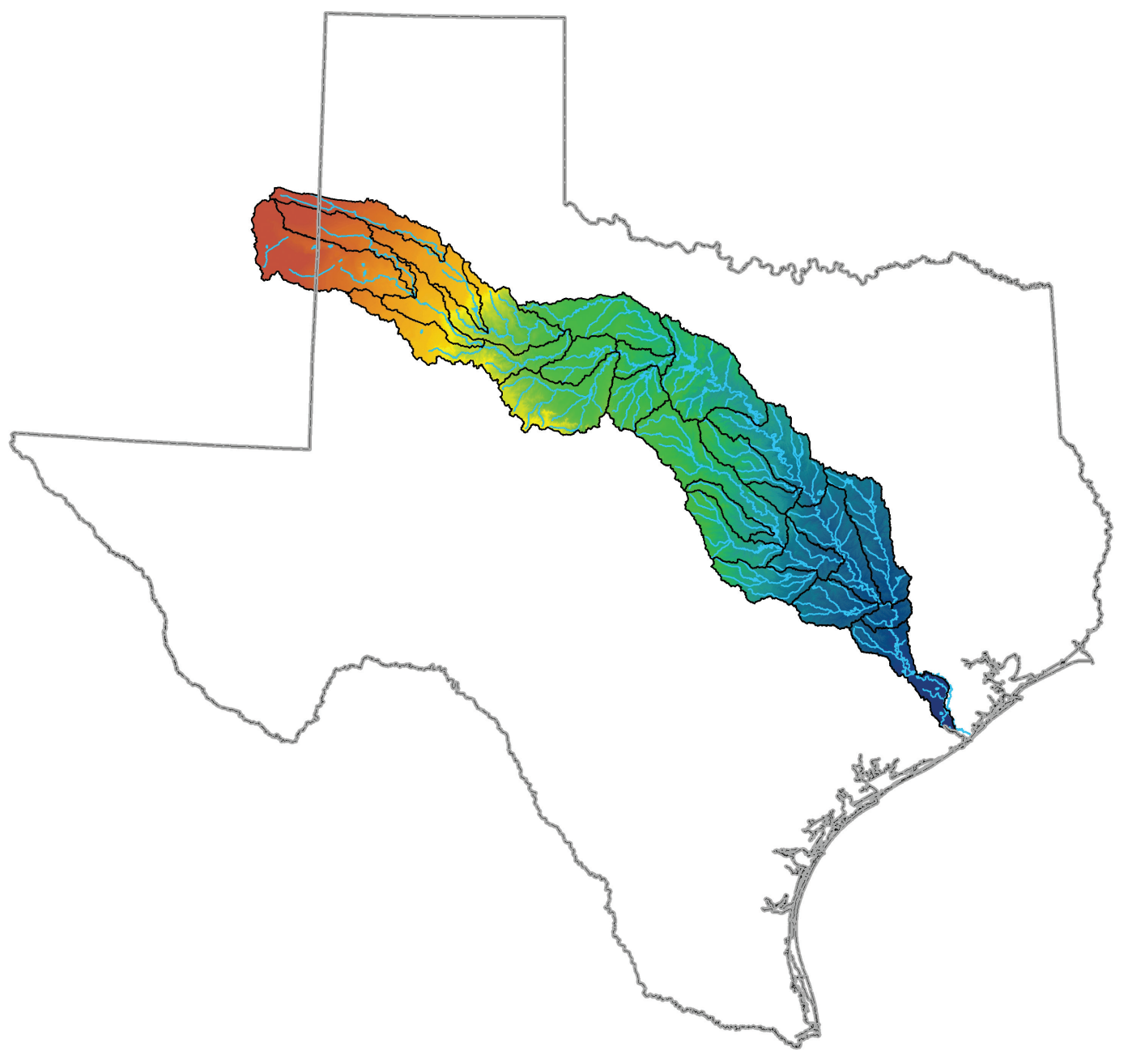

Open-File Report 2012-1077 
Cover: Cover depicts an example of the delineation and characterization of watersheds (along with their elevations) for the Brazos River Basin. 


\section{Automated Delineation and Characterization of Watersheds for more than 3,000 Surface- Water-Quality Monitoring Stations Active in 2010 in Texas}

By Christy-Ann M. Archuleta, Sophia L. Gonzales, and David R. Maltby II

Prepared in cooperation with the Texas Commission on Environmental Quality

Open-File Report 2012-1077 


\title{
U.S. Department of the Interior \\ KEN SALAZAR, Secretary \\ U.S. Geological Survey \\ Marcia K. McNutt, Director
}

\section{U.S. Geological Survey, Reston, Virginia: 2012}

\author{
This and other USGS information products are available at http://store.usgs.gov/ \\ U.S. Geological Survey \\ Box 25286, Denver Federal Center \\ Denver, CO 80225 \\ To learn about the USGS and its information products visit http://www.usgs.gov/ \\ 1-888-ASK-USGS
}

\begin{abstract}
Any use of trade, product, or firm names is for descriptive purposes only and does not imply endorsement by the U.S. Government.

Although this report is in the public domain, permission must be secured from the individual copyright owners to reproduce any copyrighted materials contained within this report.
\end{abstract}

Suggested citation:

Archuleta, C.M., Gonzales, S.L., and Maltby, D.R., II, 2012, Automated delineation and characterization of watersheds for more than 3,000 surface-water-quality monitoring stations active in 2010 in Texas: U.S. Geological Survey OpenFile Report 2012-1077, 33 p. 


\section{Contents}

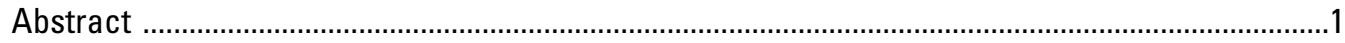

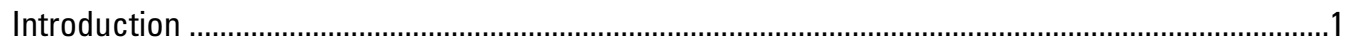

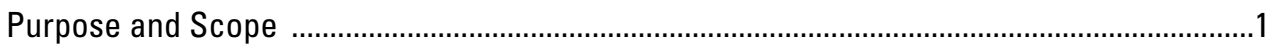

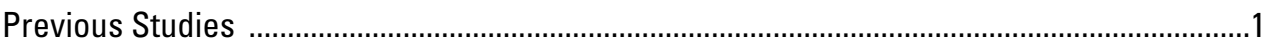

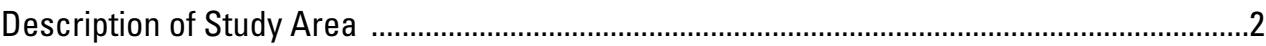

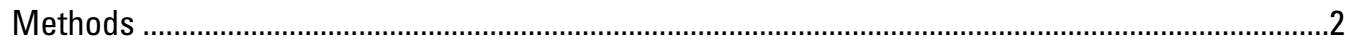

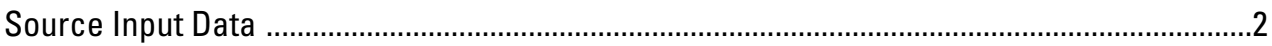

Automated Elevation Data Processing and Organization .......................................................

Automated Watershed Boundary Delineation ....................................................................

Web-Based Review System and Additional Quality-Control Processes ..................................

Computing Watershed Characteristics ..............................................................................

Limitations to the Delineated Watershed Boundary Accuracy ..............................................

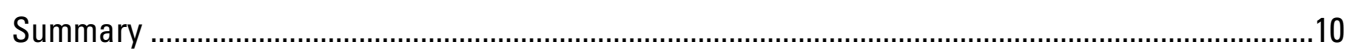

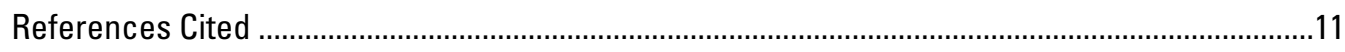

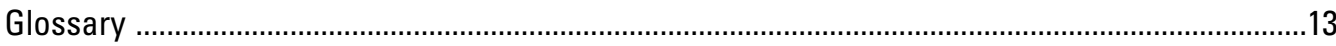

Appendixes

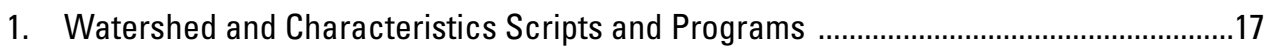

2. Watershed and Characteristics, Methods or Processes ..................................................20

\section{Figures}

1. Map showing Texas Commission on Environmental Quality surface-water-quality monitoring stations active in 2010, Watershed Boundary Dataset Regions 11, 12, and 13

2. Map showing hierarchy and areas for the six nested levels of hydrologic units .............5

3. Map showing digital elevation models (DEMs) for Texas: $A, 10$-meter DEMs mosaicked to cover Watershed Boundary Dataset Regions 11, 12, and 13.

$B$, 3-meter DEMs, where available, mosaicked to cover the Texas coastline

4. Diagram showing conceptual hydrologic flow model of elevation data derivatives.

$A$, Example Digital Elevation model (DEM) with elevation values in each cell.

$B$, Direction codes (integer numbers) assigned to cells in flow direction grids in part

A. $C$, Flow direction grid created from the example DEM in part $A$; $D$, Flow direction arrows created from the flow direction grid in part $C$. E, Flow accumulation grid created from flow direction grid in part $\mathrm{C}$ where the larger numbers and darker colors represent greater accumulated flow

5. Map showing example of watershed boundaries delineated to the extent of the Subbasin boundary defined by the Watershed Boundary Dataset 8-digit hydrologic unit code

\section{Table}

1. Primary input datasets, resolution, and scale used for delineating watersheds of active Texas Commission on Environmental Quality surface-water-quality monitoring stations, 2010 


\section{Conversion Factors}

\section{SI to Inch/Pound}

\begin{tabular}{lcl}
\hline \multicolumn{1}{c}{ Multiply } & By & \multicolumn{1}{c}{ To obtain } \\
\hline centimeter $(\mathrm{cm})$ & Length & inch (in.) \\
millimeter $(\mathrm{mm})$ & 0.3937 & inch (in.) \\
meter $(\mathrm{m})$ & 0.03937 & foot (ft) \\
kilometer $(\mathrm{km})$ & 3.281 & mile (mi) \\
\hline & 0.6214 & square foot $\left(\mathrm{ft}^{2}\right)$ \\
\hline square meter $\left(\mathrm{m}^{2}\right)$ & Area & square mile $\left(\mathrm{mi}^{2}\right)$ \\
square kilometer $\left(\mathrm{km}^{2}\right)$ & 10.76 & \\
\hline & 0.3861 & gallon $(\mathrm{gal})$ \\
\hline cubic meter $\left(\mathrm{m}^{3}\right)$ & Volume & million gallons $(\mathrm{Mgal})$ \\
cubic meter $\left(\mathrm{m}^{3}\right)$ & 264.2 & acre-foot $(\mathrm{acre}-\mathrm{ft})$ \\
cubic hectometer $\left(\mathrm{hm}^{3}\right)$ & 0.0002642 & \\
\hline & 810.7 & cubic foot per second $\left(\mathrm{ft}^{3} / \mathrm{s}\right)$ \\
\hline cubic meter per second $\left(\mathrm{m}^{3} / \mathrm{s}\right)$ & Flow rate & cubic foot per day $\left(\mathrm{ft}^{3} / \mathrm{d}\right)$ \\
cubic meter per day $\left(\mathrm{m}^{3} / \mathrm{d}\right)$ & 35.31 & million gallons per day $(\mathrm{Mgal} / \mathrm{d})$ \\
\hline cubic meter per second $\left(\mathrm{m}^{3} / \mathrm{s}\right)$ & 35.31 & foot per mile $(\mathrm{ft} / \mathrm{mi})$ \\
\hline meter per kilometer $\left(\mathrm{m} / \mathrm{km}^{3}\right)$ & 22.83 &
\end{tabular}

Vertical coordinate information is referenced to the North American Vertical Datum of 1988 (NAVD 88).

Horizontal coordinate information is referenced to the North American Datum of 1983 (NAD 83). 


\section{Acronyms}

$\begin{array}{ll}\text { DEM } & \text { Digital Elevation Model } \\ \text { DBF } & \text { Database file format extension (.DBF) } \\ \text { GIS } & \text { Geographic Information System } \\ \text { HUC } & \text { Hydrologic Unit Code } \\ \text { ID } & \text { Identification number } \\ \text { NHD } & \text { National Hydrography Dataset } \\ \text { PRISM } & \text { Parameter-elevation Regressions on Independent Slopes Model } \\ \text { StratMap } & \text { Strategic Mapping Program } \\ \text { TCEQ } & \text { Texas Commission on Environmental Quality } \\ \text { TNRIS } & \text { Texas Natural Resources Information System } \\ \text { USEPA } & \text { U.S. Environmental Protection Agency } \\ \text { USGS } & \text { U.S. Geological Survey } \\ \text { VB } & \text { Visual Basic } \\ \text { WBD } & \text { Watershed Boundary Dataset }\end{array}$





\title{
Automated Delineation and Characterization of Watersheds for more than 3,000 Surface-Water-Quality Monitoring Stations Active in 2010 in Texas
}

\author{
By Christy-Ann M. Archuleta, Sophia L. Gonzales, and David R. Maltby II
}

\begin{abstract}
The U.S. Geological Survey (USGS), in cooperation with the Texas Commission on Environmental Quality, developed computer scripts and applications to automate the delineation of watershed boundaries and compute watershed characteristics for more than 3,000 surface-water-quality monitoring stations in Texas that were active during 2010. Microsoft Visual Basic applications were developed using ArcGIS ArcObjects to format the source input data required to delineate watershed boundaries. Several automated scripts and tools were developed or used to calculate watershed characteristics using Python, Microsoft Visual Basic, and the RivEX tool. Automated methods were augmented by the use of manual methods, including those done using ArcMap software. Watershed boundaries delineated for the monitoring stations are limited to the extent of the Subbasin boundaries in the USGS Watershed Boundary Dataset, which may not include the total watershed boundary from the monitoring station to the headwaters.
\end{abstract}

\section{Introduction}

The Texas Commission on Environmental Quality (TCEQ) Surface Water Quality Monitoring Program maintains a database of more than 8,000 surface-water-quality monitoring stations to evaluate physical, chemical, and biological characteristics of the State's surface water. In 2010, more than 3,000 of these monitoring stations were actively being used. The data collected at each monitoring station are used to characterize water quality in Texas surface waters for ongoing regulatory activities, such as permitting actions, development of water-quality standards, and aquatic-habitat assessments.

This information is reported to the U.S. Environmental Protection Agency (USEPA) in the Texas Integrated Report for Clean Water Act Sections 305(b) (Texas Commission on Environmental Quality, 2010).

When water quality at a given monitoring station does not meet water-quality standards, a plan for remediation is developed. Watershed characteristics, such as precipitation, elevation, slope, land use, and total drainage area statistics are critical components of such plans; these types of data are needed for accurate water-quality assessments and can be used by the State in the assessment of water-quality-monitoring data collected at TCEQ stations. Accordingly, the USGS, in cooperation with the TCEQ, delineated high-resolution watershed boundaries and computed selected watershed characteristics for more than 3,000 surface-water-quality monitoring stations that were active in Texas during 2010.

\section{Purpose and Scope}

This report documents the computer scripts and applications developed to automate the delineation of watershed boundaries and compute selected watershed characteristics for more than 3,000 surface-water-quality monitoring stations in Texas that were active in 2010. The input source data and the automated methods used to delineate watershed boundaries are described, along with the methods used to compute the selected watershed characteristics. Limitations of the watershed boundaries and characteristics are described.

\section{Previous Studies}

In 2000, the USGS in cooperation with TCEQ (then known as the Texas Natural Resource Conservation Commission) developed a geodatabase of 1:24,000-scale watershed boundaries and characteristics in the lower Rio Grande/Rio Bravo Basin in Texas. The study area encompassed TCEQ surface-water-quality monitoring stations along the 3,220 kilometers (about 2,000 miles) of streams in the lower Rio Grande/ Rio Bravo Basin in Texas; the watershed database included data for watershed boundaries delineated to a 1:24,000-scale, selected watershed characteristics, and hydrologic derivative datasets (Brown and others, 2000). Brown and others (2000, p. 1) stated that "issues such as water quality, water allocation, drought, flood management, as well as aquatic habitat protection and management all depend on watershed-level data, and watershed boundaries frequently are used in studies dealing with these types of issues." 
Brown and others (2000) used an automated watershed boundary delineation procedure to create hydrologic datasets from 30-meter digital elevation data using Arc/Info software version 7.2.1. The automated routines were reviewed by Brown and others (2000) using 3.75-minute (1:12,000-scale) digital orthophoto quadrangles (DOQs), existing watershed boundary maps, and USGS topographic maps, and they found the resolution of the elevation datasets at that time did not reflect the most recent changes in the landscape and, therefore, did not always match the current hydrography as interpreted from digital orthoimagery. For watersheds near the Gulf of Mexico, where there is little relief, manual methods were used to correct the watershed boundaries, as the hydrologic datasets did not accurately represent drainage patterns near the coast. Brown and others $(2000$, p. 1) concluded that "the creation of a computer-generated, standardized, watershed dataset that is vertically integrated with existing hydrography will continue to be difficult until revisions can be made to existing source datasets. Until such time, manual delineation will be necessary to make adjustments to watersheds delineated with automated techniques [because of] man-made features and changes in the natural landscape that are not reflected in the digital elevation data." Finer scale data (10-meter, and in some cases, 3-meter data) has become available for watersheds throughout the United States since 2000, facilitating the use of automated methods for delineating watersheds and their characteristics.

\section{Description of Study Area}

The TCEQ surface-water-quality monitoring stations are located in Texas along an approximately 307,700-kilometer (about 191,196 miles) stream network. The watershed boundaries and watershed characteristics are described in the context of the USGS Watershed Boundary Dataset. All of the streams in Texas are located within Regions 11, 12, and 13 of the Watershed Boundary Dataset (U.S. Geological Survey, 2011). Regions 11, 12, and 13 correspond to the Watershed Boundary Dataset 2-digit hydrologic unit codes (fig. 1).

\section{Methods}

Methods for delineating watershed boundaries can be categorized as either manual or automated. Manual methods include drawing watershed boundaries by hand using a USGS topographic paper map and a pencil, or by viewing a digitized USGS topographic map on a computer screen while digitally drawing watershed boundaries. Another manual watershed boundary delineation method uses software packages, such as ESRI ArcMap (Environmental Systems Research Institute, 2012), which delineate watershed boundaries individually by using a variety of input datasets and algorithms. Manual methods of delineating watershed boundaries are timeconsuming, requiring many hours of interpretation. Automated watershed boundary delineation methods use computer scripts, custom-programmed computer applications, or both, to automatically apply and repeat the manual methods iteratively. Automated methods greatly decrease the time required to delineate watershed boundaries.

In this study, more than 3,000 watershed boundaries required delineation. Automated watershed boundary delineation methods were developed to decrease the time required to delineate watershed boundaries compared to manual methods. The use of automated methods also helps ensure that consistent results are produced efficiently. Automated computer methods were developed by using scripts written in the Python programming language (Python Software Foundation, 2011) and by using scripts and applications written in Microsoft Visual Basic. These scripts and applications work with Environmental Systems Research Institute (ESRI) ArcGIS applications (Environmental Systems Research Institute, Inc., 2008a) to facilitate completion of the delineation and characterization tasks. While the emphasis of this report is the automated methods that were developed, manual methods (when used) are described.

\section{Source Input Data}

Source input data were acquired to delineate the watershed boundaries and compute watershed characteristics. Table 1 lists the primary input datasets used in this study, along with scale and resolution of the data.

The USGS National Elevation Dataset (NED) digital elevation models (DEMs) (U.S. Geological Survey, 2009) were used to derive the elevation-derivative datasets and other terrain information necessary to delineate watershed boundaries. Elevation is of particular interest during watershed delineation because areas with relatively large amounts of topographic relief have well-defined ridges that define watershed boundaries, whereas areas with relatively small amounts of relief have poorly defined ridges, making it difficult to delineate watershed boundaries. A DEM is a digital data representation of cartographic information in a raster form, consisting of terrain elevation values for ground positions at regularly spaced horizontal intervals (U.S. Geological Survey, 2009). In geographic information systems (GIS), a raster is a type of geospatial data. Rasters are essentially digital images made of equal-sized cells organized in rows and columns. Cells in a raster can be compared to pixels in a digital picture; each cell or pixel in a raster represents information for a specific area of a specific size on the surface of the earth. The size of the area represented by the cells in a raster is referred to as resolution and can vary greatly in size from 1-meter by 1 -meter cells to 4-kilometer by 4-kilometer cells. Rasters can represent discrete data such as land use, or continuous data such as temperature or elevation. The USGS National Map Program produces the NED DEMs in 30-meter, 10-meter, and 3-meter resolution for the conterminous United States (U.S. Geological Survey, 2012). 


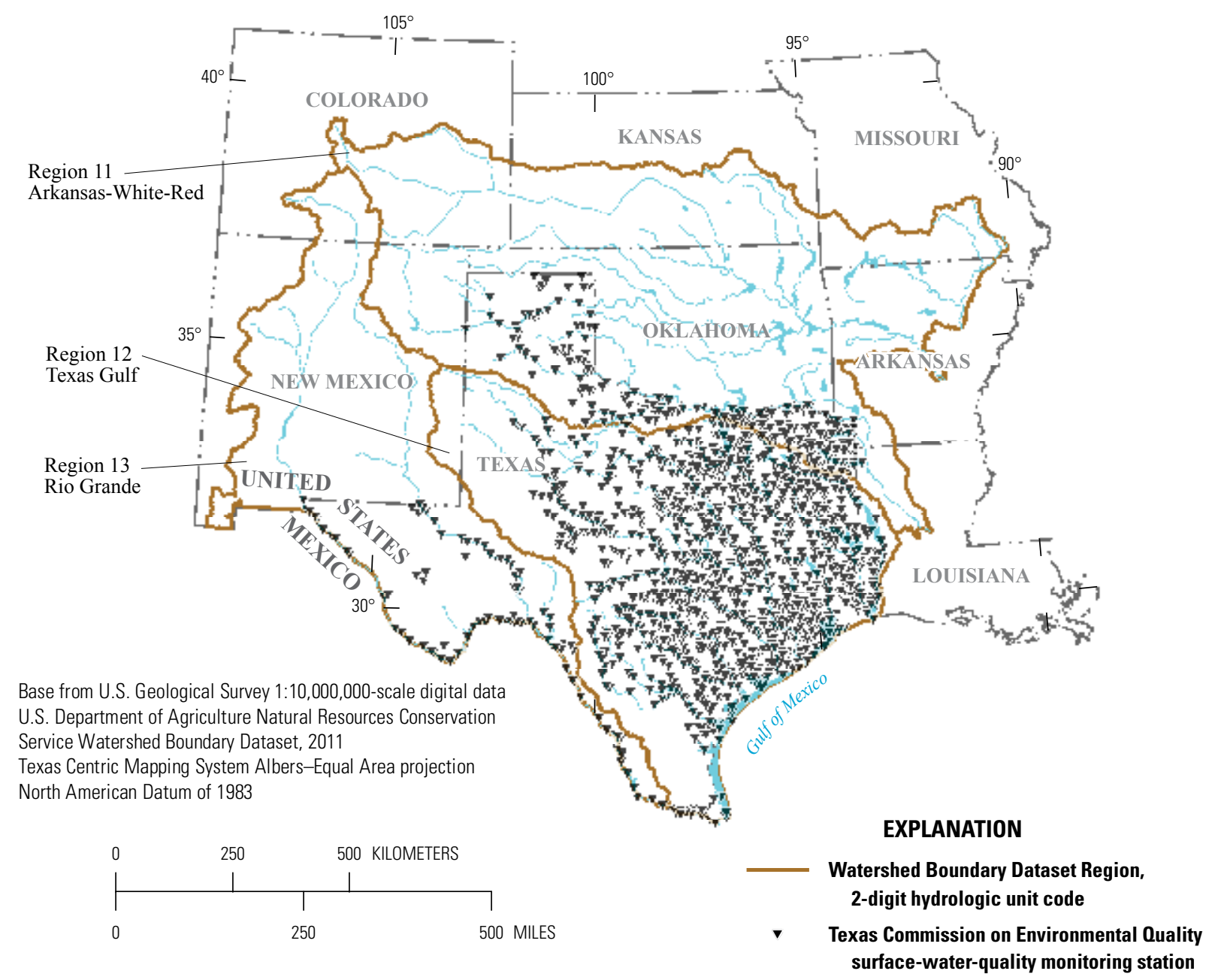

Figure 1. Texas Commission on Environmental Quality surface-water-quality monitoring stations active in 2010, Watershed Boundary Dataset Regions 11, 12, and 13.

In addition to the DEMs, other source input data used to delineate watershed boundaries were the standardized watershed boundaries in the Watershed Boundary Dataset (WBD). The WBD divides the United States into 21 Regions (U.S. Department of Agriculture, Natural Resources Conservation Service, 2011) and establishes a standardized base-line watershed boundary framework, accounting for all land and surface areas in the United States (U.S. Department of Agriculture, Natural Resources Conservation Service, 2008). The 21 Regions are divided and subdivided into successively smaller hydrologic units forming a hierarchy of surface-water drainage. This hierarchy is classified into six levels: Regions, Subregions, Basins, Subbasins, Watersheds, and Subwatersheds. Each hydrologic unit in the WBD is assigned a unique identifier called a Hydrologic Unit Code (HUC) that correlates to its position within the six nested levels of the dataset hierarchy: 2-digit codes for Regions; 4-digit codes for Subregions; 6-digit codes for Basins; 8-digit codes for Subbasins; 10-digit codes for Watersheds, and 12-digit codes for Subwatersheds (fig. 2).

Other source input datasets used were the National Land Cover Dataset of 2001 (U.S. Geological Survey, 2008), Parameter-elevation Regression on Independent Slopes Models (PRISM) (Parameter-elevation Regressions on Independent Slopes Model (PRISM) Climate Group, 2004), the Texas Natural Resources Information Service StratMap dataset (Texas Water Development Board, Texas Natural Resources Information System, 2008), and the National Hydrography Dataset (NHD) (U.S. Geological Survey, 2011). The data in these datasets were extracted and used to compute the predefined watershed characteristics. 
Table 1. Primary input datasets, resolution, and scale used for delineating watersheds of active Texas Commission on Environmental Quality surface-water-quality monitoring stations, 2010.

\begin{tabular}{ll}
\hline \multicolumn{1}{c}{ Dataset } & \multicolumn{1}{c}{ Resolution or scale } \\
\hline USGS Digital Elevation Model (DEM) $^{1}$ & 3,10 or 30 meter \\
Watershed Boundary Dataset (WBD) $^{2}$ & $1: 24,000$ \\
National Land Cover Database 2001 (NLCD) & 30 meter \\
Parameter-elevation Regressions on Independent Slopes Model (PRISM) & 4 kilometer \\
Texas Natural Resources Information Service StratMap Version 2 - & Accuracy is dependent on geographic area and sources \\
$\quad$ Transportation & used to update those areas \\
National Hydrography Dataset (NHD) & $1: 24,000$ \\
\hline
\end{tabular}

${ }^{1}$ U.S. Geological Survey, 2009.

${ }^{2}$ U.S. Department of Agriculture, Natural Resources Conservation Service, 2011.

${ }^{3}$ U.S. Geological Survey, 2008.

${ }^{4}$ PRISM Climate Group, 2004.

${ }^{5}$ Texas Water Development Board, Texas Natural Resources Information System, 2006-08.

${ }^{6}$ U.S. Geological Survey, 2011.

\section{Automated Elevation Data Processing and Organization}

The steps used to derive elevation-derivative datasets and terrain information necessary to delineate watershed boundaries are as follows:

1. Create a seamless DEM dataset,

2. Extract DEM data by Subbasins,

3. Fill DEMs,

4. Create flow direction grids, and

5. Create flow accumulation grids.

DEM data in 10-meter resolution covering the extent of WBD Regions 11, 12 and 13 were mosaicked (electronically pieced together) into one seamless dataset for the composite area represented by these Regions (fig. 3A); 3-meter DEMs were acquired where available (primarily along the Texas coast of the Gulf of Mexico) and mosaicked into a seamless dataset (fig. 3B).

A Microsoft Visual Basic Application (hereinafter referred to as the "elevation processing application") was developed using ESRI ArcGIS ArcObjects software (hereinafter referred to ArcObjects) to prepare a seamless DEM dataset. This DEM dataset was used to create the elevation derivative datasets necessary for delineating watershed boundaries as well as to create necessary derivative datasets. For each Subbasin in Regions 11, 12 and 13, the elevation processing application selects an individual Subbasin and applies a 100meter buffer (Environmental Systems Research Institute, Inc., 2008 b) creating a new buffered polygon feature class of the Subbasin. The buffered Subbasin feature class is then used to extract, or clip the seamless DEM dataset. After the DEM data is extracted to match the spatial extent of the buffered Subbasin feature class, the elevation processing application identifies sinks in the extracted DEM.

A sink (also known as a depression or pit) is a cell or group of cells in a DEM surrounded by cells with appreciably higher elevation values. Sinks may be natural features of the landscape represented by the DEM, but many sinks found in DEMs are produced from erroneous data. Sinks should be accounted for before attempting to delineate watershed boundaries because sinks prevent downslope flow routing of water, and the presence of sinks may result in an erroneous flowdirection raster (Environmental Systems Research Institute, Inc., 2009a). To account for sinks in the DEMs, the elevation processing application initiates the "Fill" function included in the ArcGIS Spatial Analyst extension to create filled (sinkless) DEMs for each of the Subbasins for use in creating the elevation derivative datasets necessary to delineate watershed boundaries.

Flow direction and flow accumulation grids are elevation derivative datasets necessary to delineate watershed boundaries. To create flow direction grids, the elevation processing application initiates the "Flow Direction" function in the ArcGIS Spatial Analyst extension using the filled DEMs as data inputs (fig. 4A). Flow direction grids are rasters where cell values are integer numbers $(1,2,4,8,16,32,64$ or 128) representing flow direction codes in 45-degree increments of a drop of water from one cell to the next (fig. $4 B$ ). Flow direction is determined by identifying the neighboring cell with the highest positive distance weighted drop (steepest descent or maximum drop) (Venkatachalam and others, 2001). The direction code assigned to each cell depends on the eight neighboring cells; the cell with the steepest descent receives the flow and defines the direction of flow from the source 

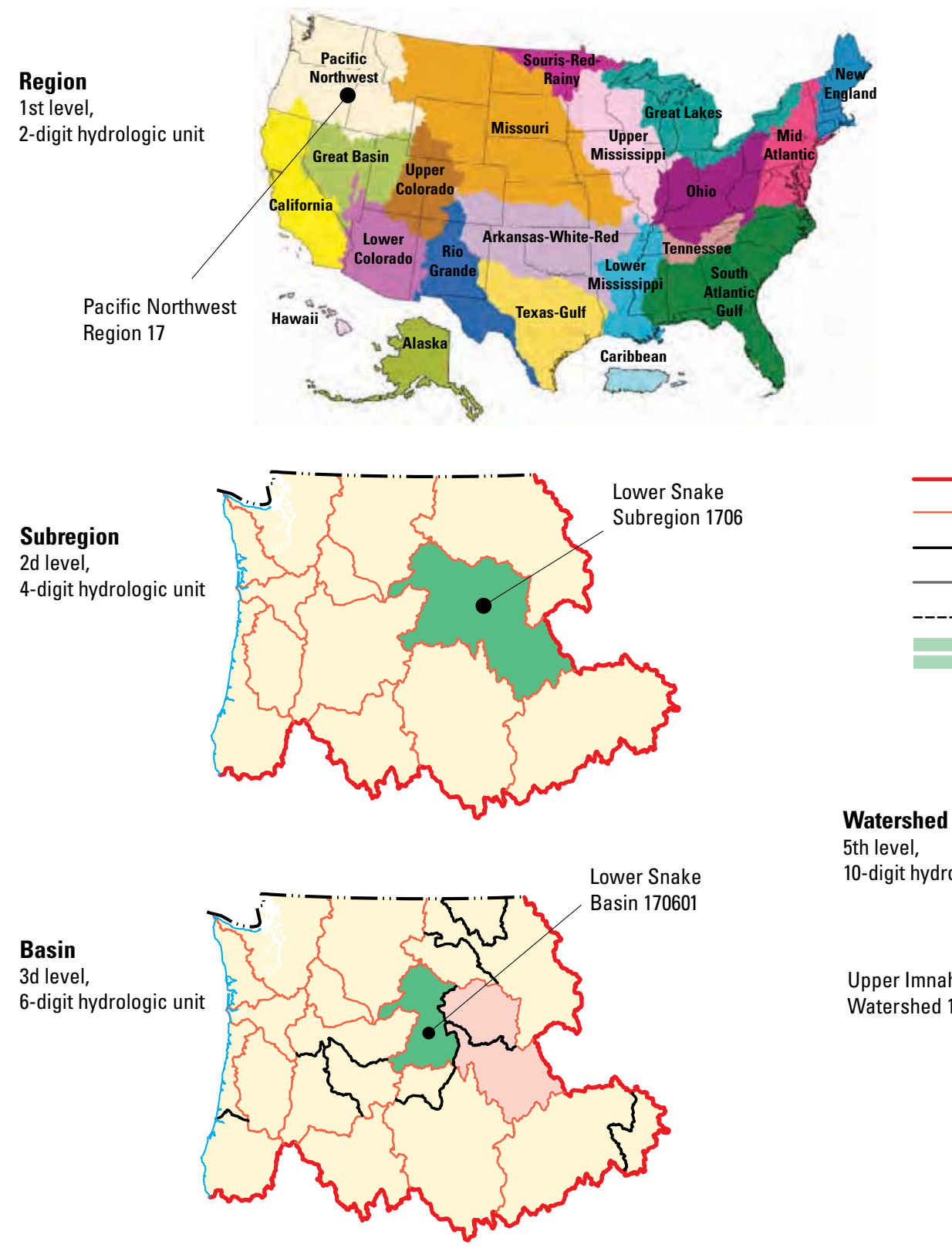

5 th level,

10-digit hydrologic unit

\section{EXPLANATION}

Hydrologic unit boundary

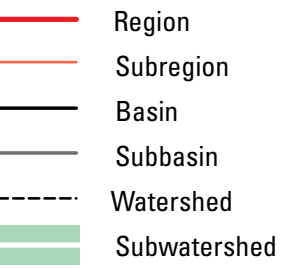

Upper Imnaha River Watershed 1706010201
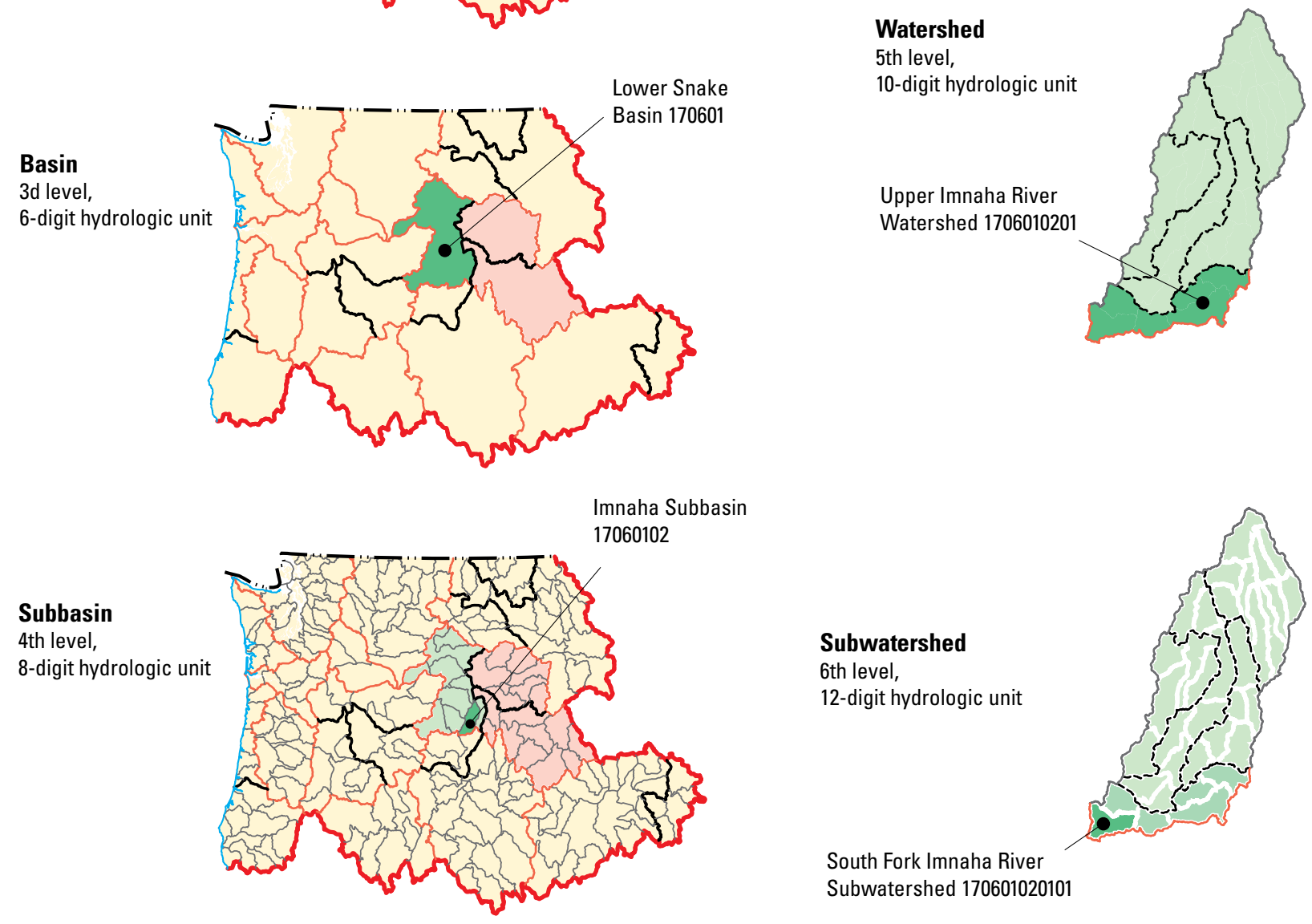

Subwatershed

6th level,

12-digit hydrologic unit

South Fork Imnaha River Subwatershed 170601020101

Figure 2. Hierarchy and areas for the six nested levels of hydrologic units are shown in the above example. Beginning with the Region level, the numbering scheme of the units increases by two digits for each subsequent level (from U.S. Geological Survey and U.S. Department of Agriculture Natural Resources Conservation Service, 2009, p. 8). 

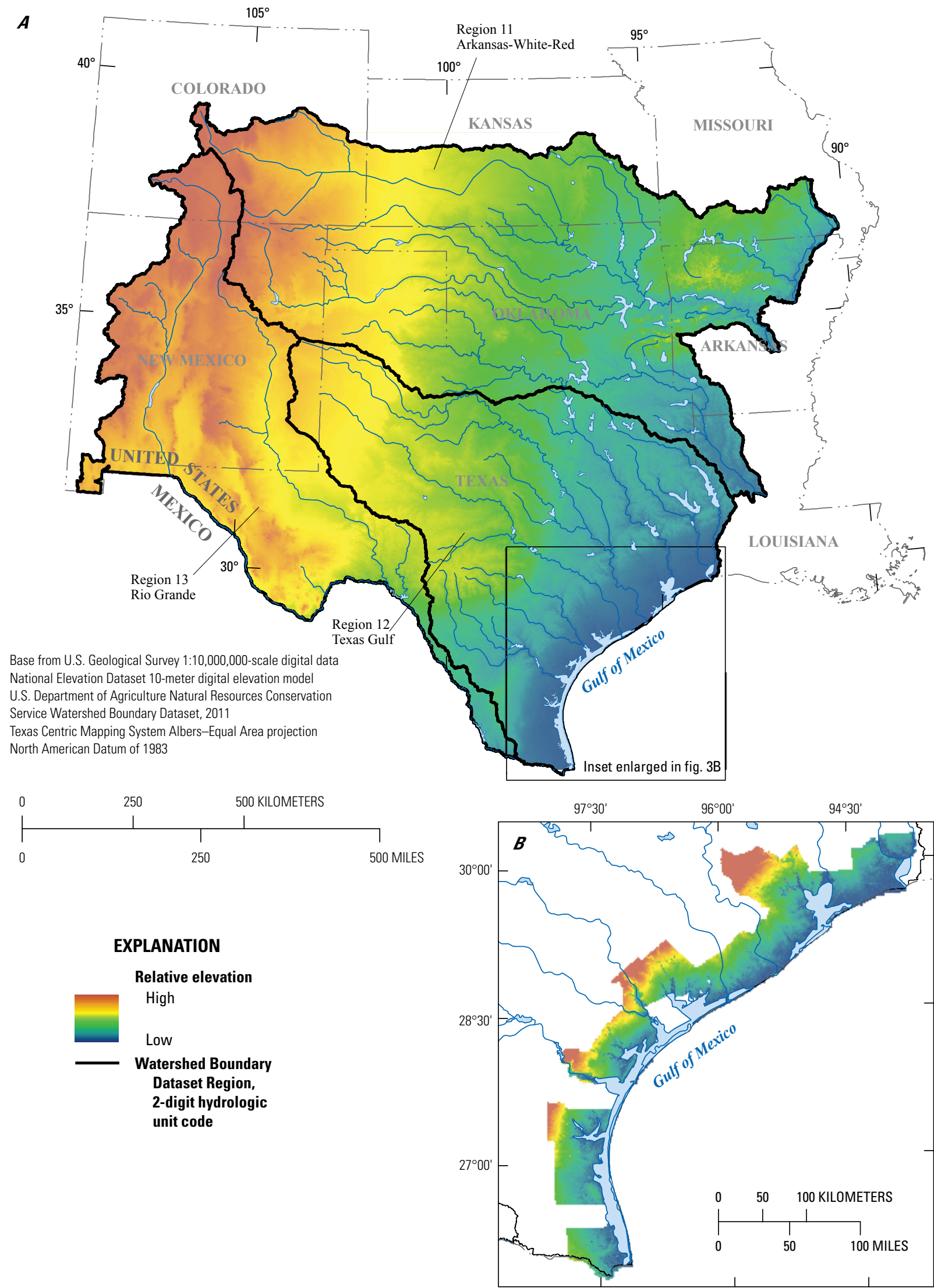

Figure 3. Digital elevation models (DEMs) for Texas: $A$, 10-meter DEMs mosaicked to cover Watershed Boundary Dataset Regions 11 , 12 , and 13. B, 3-meter DEMs, where available, mosaicked to cover the Texas coastline. 


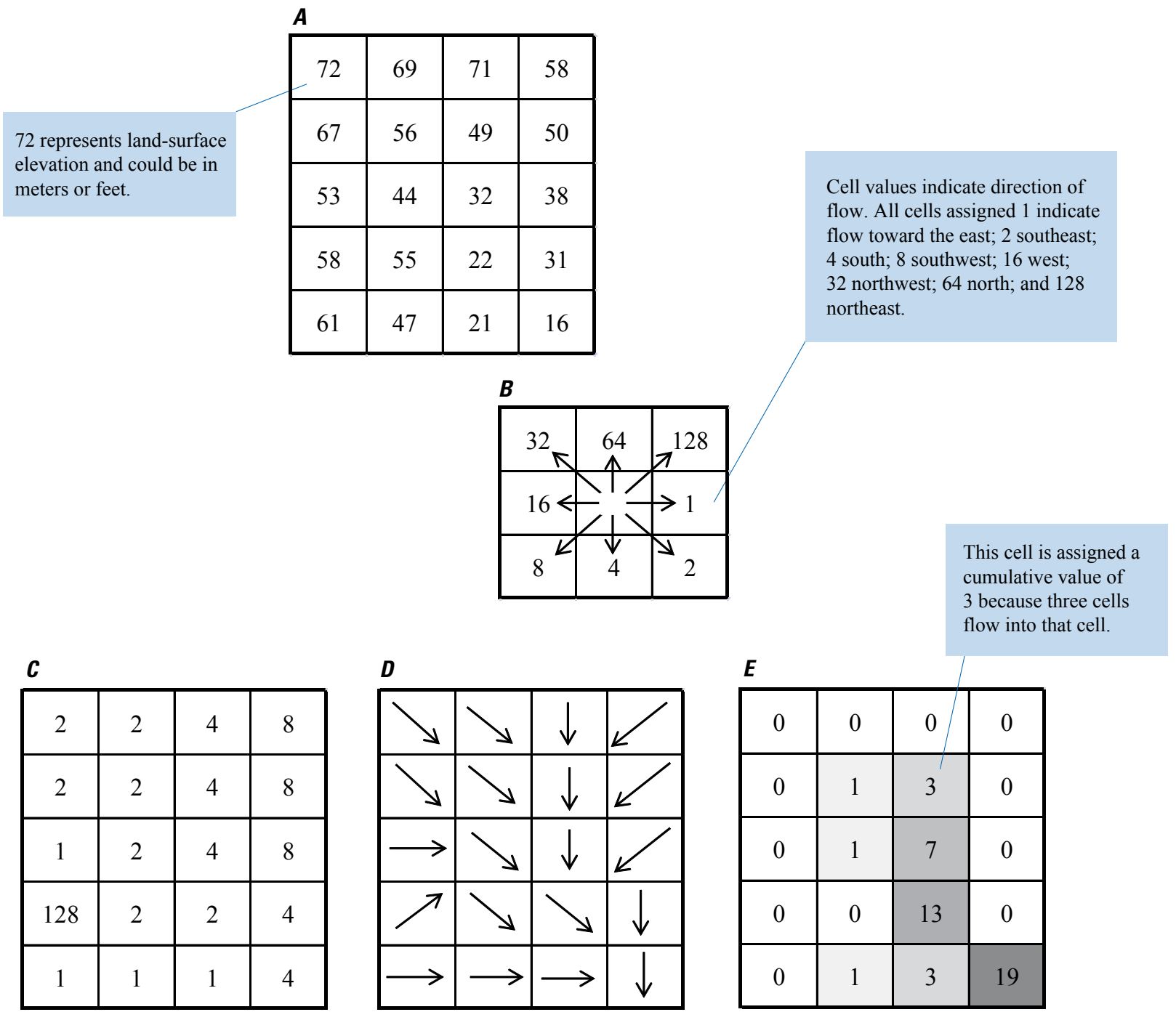

Figure 4. Conceptual hydrologic flow model of elevation data derivatives. $A$, Example Digital Elevation model (DEM) with elevation values in each cell. $B$, Direction codes (integer numbers) assigned to cells in flow direction grids in part $A$. $C$, Flow direction grid created from the example $D E M$ in part $A$; $D$, Flow direction arrows created from the flow direction grid in part $C$. $E$, Flow accumulation grid created from flow direction grid in part $\mathrm{C}$ where the larger numbers and darker colors represent greater accumulated flow.

cell (Goodwin and Tarboton, 2004) (figs. 4C and 4D). This approach is referred to as an eight direction (D8) flow model (Jenson and Domingue, 1988).

After the flow direction grids are created, the elevation processing application then creates the flow accumulation grids. Flow accumulation grids are the final elevation derivative dataset needed to delineate watershed boundaries. To create flow accumulation grids, the elevation processing application initiates the "Flow Accumulation" function in the ArcGIS Spatial Analyst extension using the flow direction grids as data inputs. Flow accumulation grids are rasters where cell values are floating point numbers representing the number of accumulated upstream cells (fig. $4 E$ ). Cells with a high flow accumulation value are areas of concentrated flow and may be used to identify stream channels. Cells with a flow accumulation value of zero are local topographic highs and may be used to identify ridges (Jenson and Domingue, 1988). A flow accumulation grid is the equivalent of drainage area measured in units of grid cells and may be used to visualize how a drainage area accumulates above streams (Olivera and others, 2002).

The elevation processing application automatically creates personal geodatabases (Environmental Systems Research Institute, Inc., 2008a) to organize the data it creates with the naming convention of the Subbasin 8-digit HUC. This 
personal geodatabase contains the selected Subbasin polygon feature class, the buffered Subbasin polygon feature class, the extracted DEM, the filled DEM, the flow direction grid, and the flow accumulation grid.

\section{Automated Watershed Boundary Delineation}

A second Microsoft Visual Basic Application (hereinafter referred to as the "watershed processing application") was developed using ArcObjects to delineate watershed boundaries from the elevation derivative datasets produced by the elevation processing application. Since flow accumulation grids define drainage area, the values in the cells of the flow accumulation grids are transformed from a count of cells to units of area to define the watershed boundaries. For the watershed boundary delineation process, the flow accumulation grids are used to define the area of all cells flowing into each downslope cell. Watershed drainage area, or watershed boundary, is equal to all cells in a flow accumulation grid that drains into a specified pour point (Paybins, 2008). This representation of the drainage area is converted into a temporary polygon representing the completed watershed boundary. In the watershed processing application, the monitoring station location points are the specified points, commonly referred to as pour points.

In the watershed processing application, watershed boundaries for each monitoring station were delineated in eight steps using the monitoring station's location points, buffered subbasin polygons, and the elevation derivative datasets produced by the elevation processing application. In the first step, the geodatabase containing the monitoring stations point feature class is accessed. In the second step, a monitoring station point feature is selected from the monitoring stations point feature class, and the longitude and latitude coordinates are extracted for the selected monitoring station's point location. In the third step, the monitoring station's coordinates are compared to the coordinates defining the Subbasin polygon boundaries to identify and select the Subbasin 8-digit HUC containing the monitoring station's point. In the fourth step, the directory containing the elevation-derivative data for the selected Subbasin 8-digit HUC is located using the naming convention organization of the data described in the previous section. In order to delineate watershed boundaries, the monitoring station's location must intersect a drainage line on a flow accumulation grid. Because the coordinates for the monitoring station's points were determined with different methods such as topographic map interpretation, or with global positioning system (GPS) units with different accuracies, they often did not intersect the drainage lines. To rectify this, the fifth step of the watershed processing application "snaps" (digitally moves in ArcGIS) the monitoring stations' points to the nearest drainage line on the flow accumulation grids using the "Snap Pour Point" Spatial Analyst function in ArcGIS. This tool searches the area around a specified point within a user-specified distance (in this case, 50 meters) for the cell of highest accumulated flow on the flow accumulation grid and moves the point to that cell location. After the monitoring station's points are snapped to drainage lines on the flow accumulation grids, they are referred to as pour points. Once the monitoring station's points are snapped into pour points, the sixth step of the watershed processing application initiates the "Calculate Watershed" function in the ArcGIS Spatial Analyst extension to determine the cells, or area that drains into the cell on the flow accumulation grid that intersects the pour point. The Calculate Watershed function uses the flow direction grids and the flow accumulation grids to determine the area contributing flow to a pour point (Environmental Systems Research Institute, Inc., 2009b). The output is a raster representation of the watershed boundary that is then converted into a temporary vector polygon and added to a monitoring station watershed boundary master feature class in the seventh step. In the eighth and final step, the pour point location is added to a separate monitoring station pour point master feature class.

\section{Web-Based Review System and Additional Quality-Control Processes}

During an initial testing and quality-control phase of this study, a web-based review system was used to facilitate quality control of the watershed boundaries, track changes to the watershed boundaries, and facilitate TCEQ input. The review system included tools for adding geocoded change requests to the watershed boundaries. The application was designed to reduce the amount of time for completing reviews compared to alternative review processes such as routing paper maps between offices, or exchanging the changes using a geodatabase that would require a GIS Analyst to interpret. Instead, the review system allowed TCEQ staff to quickly review the watershed boundaries and request changes. USGS staff reviewed the changes requested and applied them to the watershed boundaries.

In addition to the web-based review system, USGS staff used ESRI ArcMap 9.3 software to compare all of the individual watershed boundaries that were delineated to USGS topographic maps and other base maps, to the seamless 10-meter DEM grid, and to aerial photographs. If a watershed boundary was found to be inconsistent with the surface-water drainage depicted in the reference material used for comparison, the boundary was manually adjusted. Additionally, random quality-control checks were performed manually on the pour points to ensure they were snapped to the correct stream. The names of the monitoring stations were compared to the names of the NHD flow lines where the monitoring stations were snapped for consistency. Any pour points found in an incorrect location during this quality-control process were manually moved to their correct location on the flow accumulation grids and run through the watershed processing application again. 


\section{Computing Watershed Characteristics}

The monitoring station watershed boundaries delineated were attributed with selected characteristics specified by the TCEQ, including:

- Strahler and Shreve stream order,

- road density,

- minimum, maximum, and average elevation,

- relief,

- 30-year average-annual precipitation,

- land-cover percentages for 16 land-cover classes,

- riparian land-cover percentages for 14 land-cover classes, and

- channel-elevation and channel-length statistics.

Several automated scripts and tools were developed or used to calculate watershed characteristics. Scripts were written using the Python programming language (Python Software Foundation, 2011) or Microsoft Visual Basic. Extensions to ArcGIS provided by the RivEX Tool (Hornby, 2010) were also used to calculate watershed characteristics. Tables of watershed characteristics information were related or joined to the master monitoring station watershed boundary feature class. An overview of the scripts and tools used to compute watershed characteristics is provided in appendix 1. Watershed characteristics including definition, source input data, and scripts used to compute each characteristic are provided in appendix 2 .

\section{Limitations to the Delineated Watershed Boundary Accuracy}

The delineation of watershed boundaries for the surfacewater-quality monitoring stations was limited to the extent of the Subbasin boundaries defined by the Watershed Boundary Dataset (WBD) 8-digit hydrologic unit code (fig. 5); the delineated watersheds might not include the total watershed boundary from the monitoring station to the headwaters. Constraining watershed boundary delineations to Subbasin boundaries relies on the standardized base-line drainage boundary framework found in the WBD and vastly increases the speed of preparing the DEMs and creating the flow accumulation and flow direction grids necessary to delineate watershed boundaries. Ensuring that the watershed boundaries delineated for this study were coincident with the WBD Subbasin boundaries also allows for consistency with other hydrologic units in the WBD discussed in the Source Input Data section. Watershed boundaries produced from the watershed processing application were modified, where possible, to be coincident to the WBD Subbasin boundary lines using scripts written in the Python programming language (Python Software Foundation, 2011) and in Microsoft Visual Basic. These scripts codify a series of steps to ensure continuity between watershed boundaries.

In addition to monitoring water quality in streams, the TCEQ monitors the quality of water in many reservoirs throughout Texas. Reservoirs complicate the process of delineating watershed boundaries because they obscure the natural drainage system. The size of the pool area and the amount of fluctuation in the normal pool area of a reservoir further complicates the process of delineating watershed boundaries. Because of the difficulty in delineating hydrologic unit boundaries for reservoirs, as described by the Federal Guidelines for the Watershed Boundary Dataset (U.S. Geological Survey and U.S. Department of Agriculture, Natural Resources Conservation Service, 2009), one pour point per reservoir was selected to represent the entire reservoir from the most downstream surface-water-monitoring station on the reservoir, usually at the dam impounding the reservoir. Any additional surface-water-monitoring stations within the reservoir boundary or on the reservoir were excluded from the watershed boundary delineation process. The monitoring station points selected to represent the reservoir were manually moved in ArcMap 9.3 to a location on the flow accumulation grids directly downstream from the associated reservoir dam to facilitate watershed boundary delineation. 


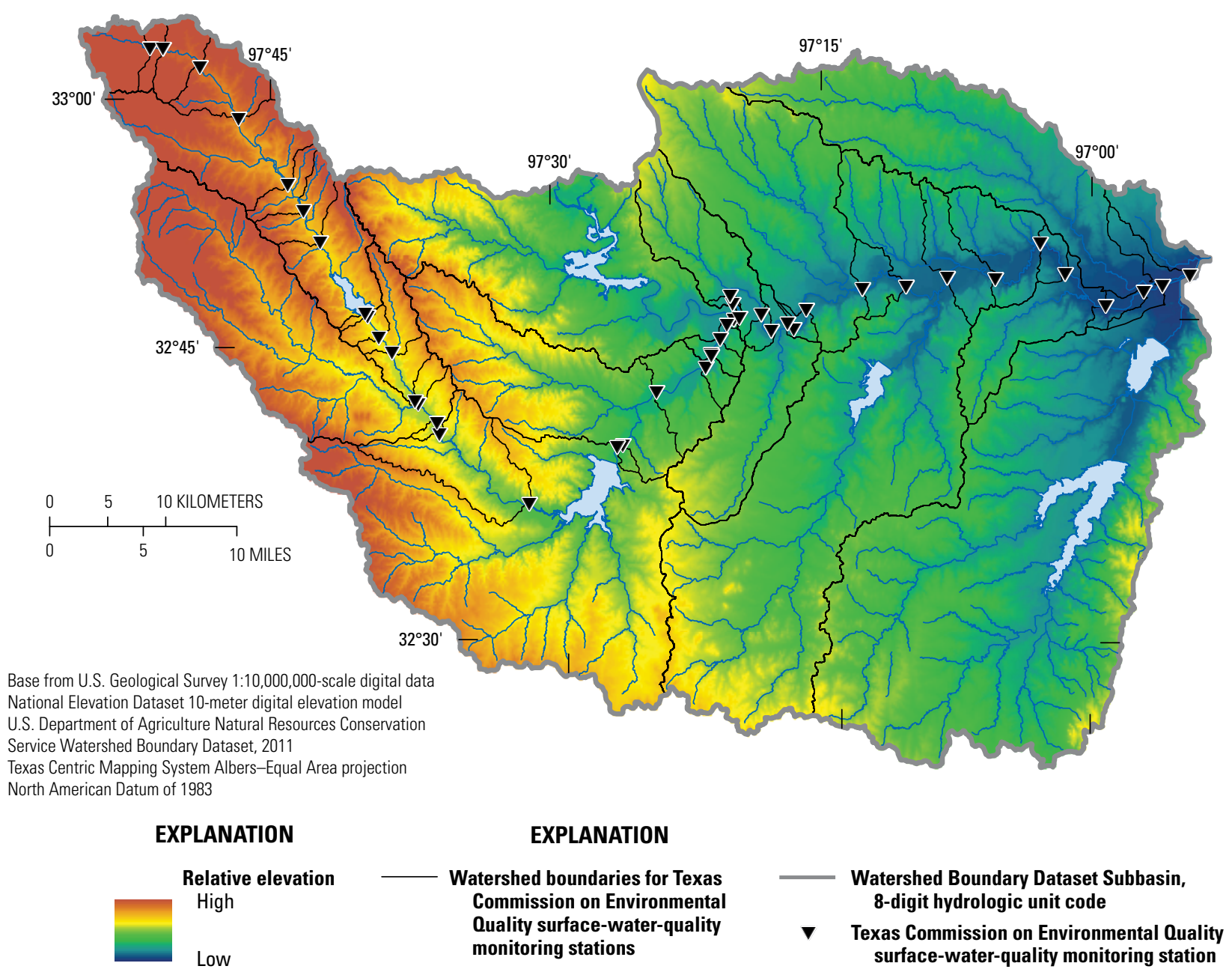

Figure 5. Example of watershed boundaries delineated to the extent of the Subbasin boundary defined by the Watershed Boundary Dataset 8-digit hydrologic unit code.

\section{Summary}

The Texas Commission on Environmental Quality (TCEQ) Surface Water Quality Monitoring Program maintains a database of more than 8,000 surface-water-quality monitoring stations to evaluate physical, chemical, and biological characteristics of the State's surface water. In 2010, more than 3,000 of these monitoring stations were actively in use. The data collected at each monitoring station are used to characterize water quality in Texas surface waters for ongoing regulatory activities, such as permitting actions, development of water-quality standards, and aquatic-habitat assessments. Watershed characteristics, such as precipitation, elevation, slope, land use, and total drainage area statistics also are critical for ongoing regulatory activities. Accordingly, the U.S. Geological Survey (USGS), in cooperation with the TCEQ, delineated high-resolution watershed boundaries and computed selected watershed characteristics for more than 3,000 surface-water-quality monitoring stations that were active in Texas during 2010. The USGS National Elevation Dataset (NED) digital elevation models (DEMs) were used to derive the elevation derivative datasets and terrain information necessary to delineate watershed boundaries. In addition to the DEMs, other source input data used to delineate watershed boundaries were the standardized watershed boundaries in the Watershed Boundary Dataset (WBD). Other source input datasets used were the National Land Cover Dataset of 2001, Parameter-elevation Regression on Independent Slopes Models, the Texas Natural Resources Information Service StratMap dataset, and the National Hydrography Dataset. The data in these datasets were extracted and used to compute selected watershed characteristics. 
Automated methods were mostly used; these methods relied on computer scripts and applications to automatically apply and repeat manual methods iteratively. Automated methods greatly decrease the time required to delineate watershed boundaries. A Microsoft Visual Basic Application was developed to create the elevation-derivative datasets used for delineating watershed boundaries. A second Microsoft Visual Basic Application was developed to delineate the watershed boundaries from the elevation-derivative datasets produced by the elevation processing application. During an initial testing and quality-control phase of this study, a web-based review system was used to facilitate quality control of the watershed boundaries, track changes to the watershed boundaries, and facilitate TCEQ input. In addition to the web-based review system, USGS staff used ArcMap 9.3 software to compare all of the individual watershed boundaries that were delineated to USGS topographic maps and other base maps, to the seamless 10-meter DEM grid, and to aerial photographs. Several automated scripts and tools were developed or used to calculate watershed characteristics. Scripts were written using the Python programming language or Microsoft Visual Basic. Extensions to ArcGIS provided by the RivEX Tool were also used to calculate watershed characteristics. The delineation of watershed boundaries for the surface-water-quality monitoring stations was limited to the extent of the Subbasin boundaries defined by the Watershed Boundary Dataset 8-digit hydrologic unit code. Watershed boundaries produced from the watershed processing application were modified, where possible, by using scripts to be coincident to the WBD Subbasin boundary lines.

\section{References Cited}

Brown, J.R., Ulery, R.L., and Parcher, J.W., 2000, Creating a standardized watersheds database for the Lower Rio Grande/Río Bravo, Texas: U.S. Geological Survey OpenFile Report 2000-065, 17 p.

Environmental Systems Research Institute, Inc., 2008a, ArcGIS Desktop 9.2 Help_-Types of Geodatabases: ArcGIS Desktop 9.2 Help, accessed April 11, 2012 at http://webhelp.esri.com/arcgisdesktop/9.2/index. cfm?topicname=types_of_geodatabases.

Environmental Systems Research Institute, Inc., 2008b, Arc GIS Desktop 9.3 Help_Creating Buffers: ArcGIS Desktop 9.3 Help, accessed April 11, 2012 at http://webhelp.esri. com/arcgiSDEsktop/9.3/index.cfm?TopicName=Creating buffers.

Environmental Systems Research Institute, Inc., 2009a, ArcGIS Desktop 9.3 Help_Creating a depressionless DEM: ArcGIS Desktop 9.3 Help, accessed January 4, 2011, at http://webhelp.esri.com/arcgisdesktop/9.3/index. cfm? TopicName $=$ Creating_a_depressionless_DEM.
Environmental Systems Research Institute, Inc., 2009b, ArcGIS Desktop 9.3 Help—Snap Pour Point: ArcGIS Desktop 9.3 Help, accessed January 4, 2011, at http://webhelp.esri. com/arcgisdesktop/9.3/index.cfm?id=6261\&pid=6253\&topi cname=Snap_Pour_Point.

Environmental Systems Research Institute, 2012, ArcGIS-Mapping and analysis for understanding our world: accessed April 20, 2012, at http://www.esri.com/software/ arcgis/.

Goodwin, C.A., and Tarboton, D.G., 2004, Morphometric properties, in Goudie, A.S., Encyclopedia of Geomorphology v. 2: New York, Routledge, p. 697.

Hornby, D. D., 2010, RivEX software (Version $\boldsymbol{X}$ ): Available from http://www.rivex.co.uk.

Jenson, S.K., and Domingue, J.O., 1988, Extracting topographic structure from digital elevation data for Geographic Information System analysis: Photogrammetric Engineering and Remote Sensing, v. 54, no.11, p. 1593-1600.

Nagel, D., 2003, ArcGIS instructions for computing road density per watershed and identifying stream crossings: U.S. Forest Service, accessed August 25, 2010, at http://www.fs.fed.us/rm/boise/research/gis/documents/ ArcGISRoadDensityStreamCrossing.pdf.

Olivera, F., Furnans, J.E., Maidment, D.R., Djokic, D., and Ye, Z., 2002, Drainage systems. in Maidment, D.R., Arc hydro: GIS for water resources, v. 1: Redlands, California, Environmental Systems Research Institute, Inc., p. 70-72.

Parameter-elevation Regressions on Independent Slopes Model (PRISM) Climate Group, 2004, Oregon State University: online at http://prism.oregonstate.edu.

Paybins, K.S., 2008, Basin characteristics for selected streamflow-gaging stations in and near West Virginia: U.S. Geological Survey Open-File Report 2008-1087, 9 p. Available at http://pubs.usgs.gov/of/2008/1087.

Python Software Foundation, 2011, Python software foundation home page, accessed October 11, 2011, at http://www. python.org/psf/.

Shreve, R.L., 1966, Statistical law of stream numbers: Journal of Geology, v. 74, p. 17-34.

Shreve, R.L., 1967, Infinite topologically random channel networks: Journal of Geology, v. 75, p. 178-186.

Strahler, A.N., 1952, Hypsometric (area-altitude) analysis of erosional topography: Geological Society of America Bulletin, v. 63, p. 1120. 
Texas Commission on Environmental Quality, 2010, Texas integrated report for clean water act sections (305(b) and 303(d): Texas Commission on Environmental Quality, accessed January 18, 2011, at http://www.tceq.state.tx.us/ compliance/monitoring/water/quality/data/wqm/305_303. html.

Texas Water Development Board, Texas Natural Resources Information System, 2008, Strategic mapping program (StratMap, version 2-transportation): accessed February 2, 2011, at http://www.tnris.org/StratMap.

U.S. Department of Agriculture, Natural Resources Conservation Service, 2008, Information about hydrologic units and the Watershed Boundary Dataset: Natural Resources Conservation Service, accessed February 2, 2011, at http://www.ncgc.nrcs.usda.gov/products/datasets/watershed/ datainfo.html.

U.S. Department of Agriculture, Natural Resources Conservation Service, 2011, Geospatial data gateway-Watershed boundary dataset-HUC 12: National Cartography and Geospatial Center, accessed March 21, 2012, at http:// www.nrcs.usda.gov/wps/portal/nrcs/main/national/water/ watersheds/dataset.

U.S. Environmental Protection Agency, 2006, National Hydrography Dataset Plus_-NHDPlus, accessed April 20, 2012, at http://www.epa.gov/waters.

U.S. Environmental Protection Agency, 2007, MultiResolution Land Characteristics Consortium National Land
Cover Dataset 2001 Land Cover Class Definitions: U.S. Environmental Protection Agency, accessed August 26, 2010, at http://www.epa.gov/mrlc/definitions.html.

U.S. Geological Survey, 2008, National Land Cover Dataset 2001: U.S. Geological Survey, accessed February 14, 2010 , at http://www.mrlc.gov/nlcd2001.php.

U.S. Geological Survey, 2009, Digital Elevation Model: U.S. Geological Survey, accessed January 4, 2011, at http://eros. usgs.gov/\#/Guides/dem.

U.S. Geological Survey, 2011, National hydrography dataset: U.S. Geological Survey, available at http://nhd.usgs.gov/ index.html.

U.S. Geological Survey, 2012, Seamless data warehouseWhat is elevation?: accessed April 20, 2012, at seamless. usgs.gov/about_elevation.php.

U.S. Geological Survey and U.S. Department of Agriculture, Natural Resources Conservation Service, 2009, Federal guidelines, requirements, and procedures for the national Watershed Boundary Dataset: U.S. Geological Survey Techniques and Methods $11-\mathrm{A} 3,55 \mathrm{p}$.

Venkatachalam, P., Mohan, B.K., Kotwal, A., Mishra, V., Muthuramkrishna, V., and Pandya, M., 2001, Automatic delineation of watersheds for hydrological applications: Paper presented at the 22nd Asian Conference on Remote Sensing, Singapore, November 5-9, 2001. 


\section{Glossary}

Application A software program that runs on a computer.

ArcGIS Server Javascript API An interface implemented by the ArcGIS Server software program to enable interaction with other software written in Javascript programming language.

Elevation derivatives Topographically derived data sets, such as flow accumulation and flow direction.

Feature class A collection of geographic features with the same geometry type (such as point, line, or polygon), the same attributes, and the same spatial reference.

Flow accumulation In a raster-based analysis, the total number of cells, including non-neighboring cells that drain into a selected cell.

Flow direction In a raster-based watershed analysis, each cell is assumed to drain into one of its eight neighbors (left, right, up, down, plus the four diagonals).

Mosaic A GIS function that combines multiple adjacent input rasters into a single raster dataset.

NHDPlus A suite of geospatial data products derived from the National Hydrography Dataset (NHD), the National Elevation Dataset (30-meter), and the National Watershed Boundary Dataset.
Pour point The point at which water flows out of an area. This is usually the lowest point along the boundary of the drainage basin.

Script A list of computer commands written for a specific computer program; commonly used to automate processes.

Strategic Mapping Program (StratMap) Produces, maintains, and enhances Texas statewide digital geographic data themes in partnership with geographic information systems (GIS) professionals from public and private organizations.

Visual Basic (VB) A computer programming system developed and owned by Microsoft, including software tools to automatically create the detailed programming required by the Windows operating system. These software tools use the graphical way that Windows works by letting programmers "draw" their systems with a mouse on the computer. This is why it is called "Visual" Basic. VB includes everything that is necessary to write programs for Windows.

Watershed The entire geographical area drained by a stream and its tributaries; an area characterized by all runoff being conveyed to the same outlet.

Watershed boundary The ridge or crest line dividing two drainage areas.

Watershed delineation The determination of the boundary between watersheds. 

Appendixes 1-2 

Appendix 1. Watershed and Characteristics Scripts and Programs.

\begin{tabular}{l} 
Script or program: CalcRdDist.vbs \\
\hline Requirements: \\
\hline Shapefile of the roads contained within the watershed. \\
Process: \\
Connects to the folder containing all shapefiles of roads per watershed. Opens the .dbf file that is part of the shapefile and sums the values in \\
the length column and writes a total value out to a text file. \\
\hline Output: \\
\hline A text file containing each watershed ID and length of roads in that watershed in kilometers. \\
\hline
\end{tabular}

\begin{tabular}{l}
\hline \multicolumn{1}{c}{ Script or program: updatewsname.vbs } \\
\hline Requirements: \\
\hline Directory of individual shapefiles of watersheds. \\
\hline Process: \\
\hline Opens each individual shapefile of the watersheds, creates a column (WsId), and populates it with the watershed ID from the file name. \\
\hline Output: \\
\hline A new column, WsId, in each individual watershed shapefile with the watershed ID of that file. \\
\hline
\end{tabular}

\begin{tabular}{l}
\hline Script or program: pPointtoSHP.vbs \\
\hline Requirements: \\
\hline Directory of raster pour points. \\
\hline Process: \\
\hline Converts each pour point raster to a point shapefile. \\
\hline Output: \\
\hline Shapefile of pour points. \\
\hline
\end{tabular}

\section{Requirements:}

\section{Script or program: SplitLayerByAttributes.py}

A feature class or shapefile with a unique identifier in text format.

\section{Process:}

Splits all features in a shapefile or feature class into individual feature classes or shapefiles based on a unique identifier.

\section{Output:}

Shapefiles or feature classes split from the input file.

\section{Script or program: convert_ws2grd.vbs}

\section{Requirements:}

Input directory of shapefiles.

\section{Process:}

Converts all shapefiles in a given directory to individual raster GRIDS in an output directory.

\section{Output:}

A directory of GRIDs, one for each shapefile in the input directory. 


\section{Script or program: Zonalstats_grd.vbs}

\section{Requirements:}

Thematic raster data, input directory of rasters to process.

\section{Process:}

Calculates zonal statistics (mean, minimum, maximum, sum, range, and standard deviation) of a raster cell values for a grid.

\section{Output:}

Fills a directory with DBF tables of zonal statistics, one for each input.

\section{Script or program: GNISidMatch.py}

\section{Requirements:}

NHD Streams with GNIS_ID field populated, pour points.

\section{Process:}

Creates a new feature class containing only stream segments with GNIS_ID's matching monitoring point GNIS_IDs.

\section{Output:}

A feature class containing NHD stream segments for water monitoring locations.

\section{Script or program: mainchannelextration.py}

\section{Requirements:}

NHD stream segments, watershed boundaries, pour points.

\section{Process:}

Clips each set of stream segments with matching GNIS_ID's to the boundary of a watershed.

\section{Output:}

A feature class containing a main channel for each monitoring point.

\section{Script or program: mcs1km.py}

\section{Requirements:}

Main channels for pour points, pour points.

\section{Process:}

Creates a route event from the main channel segments and a route event 1 kilometer upstream from a pour point of a main channel. Splits the main channel with the "to" node, calculates elevation for "FROM" and "TO" nodes, and calculates slopes for distance 1 kilometer from the pour point.

\section{Output:}

A feature class containing "FROM" and "TO" nodes for each monitoring station and the distance 1 kilometer upstream from the pour point, 1-km stream segments, and "FROM" and "TO" nodes for monitoring point and point 1 kilometer from monitoring point.

\section{Requirements:}

\section{Script or program: mcs_10_85}

Main channel stream segments and pour points.

Process:

Creates a route from the main channel segments, and routes flow from a pour point along a stream channel. Splits the main channel with the route events node, extracts elevation values for 10 percent and 85 percent nodes representing 10 and 85 percent of the flow in the channel, respectively, and calculates slopes for the distance between the 10 and 85 percent node points.

Output:

A table with 10 to 85 percent elevation and slope values for each monitoring point. 


\section{Script or program: riparianbuffer.py}

Requirements:

Stream segments, "FROM" and "TO" nodes for pour points and distance 1 kilometer upstream from pour point along a stream.

Process:

Splits stream segment 1 kilometer from a pour point, then buffers the resulting stream segment by 50 meters.

Output:

A feature class containing 1-kilometer by 50-meter buffers along stream channel for each monitoring point.

\section{Script or program: WatershedCalc.vbp}

\section{Requirements:}

Elevation derivatives, pour point feature class in a personal geodatabase, Subbasin feature class in a personal geodatabase.

\section{Process:}

Opens the point feature class looping through each point; determines which HUC-8 code the point falls in; uses the corresponding elevation derivatives for which the point falls in; calculates a watershed boundary and pour point.

Output:

A watershed shapefile per point and a raster pour point. 
Appendix 2. Watershed and Characteristics, Methods or Processes

\begin{tabular}{l} 
Attribute: Strahler stream order \\
\hline Description: \\
\hline $\begin{array}{l}\text { Numerical assignment of a segment of a stream within a stream network. Stream segments at the headwaters (top) of a stream are first-order } \\
\text { streams. When two first-order streams come together, they form a second-order stream. When two second-order streams come together, } \\
\text { they form a third-order stream. Stream order only increases when streams of the same order intersect. Therefore, the intersection of a first- } \\
\text { order and second-order stream will remain a second-order stream rather than create a third-order stream (Strahler, 1952). }\end{array}$ \\
\hline Method or process: \\
\hline The Strahler stream order was calculated using the RivEX Tool (Hornby, 2010). \\
\hline Unit: (What unit is the attribute in?) \\
\hline Integer. \\
\hline Source data used: \\
\hline NHD Plus Hydrography vector data (U.S. Environmental Protection Agency, 2006). \\
\hline
\end{tabular}

\begin{tabular}{l}
\hline \multicolumn{1}{c}{ Attribute: Shreve stream order } \\
\hline Description: \\
\hline $\begin{array}{l}\text { Numerical assignment of a segment of a stream within a stream network. Stream segments at the headwaters (top) of a stream are first-order } \\
\text { streams. When two first-order streams come together, they form a second-order stream. When two second-order streams come together, } \\
\text { they form a fourth-order stream. Magnitudes are additive downslope. When two streams intersect, their magnitudes are added and as- } \\
\text { signed to the downslope stream (Shreve, 1966; Shreve, 1967). }\end{array}$ \\
\hline Method or process: \\
\hline The Shreve stream order was calculated using RivEX Tool (Hornby, 2010). \\
\hline Unit: \\
\hline Integer. \\
\hline Source data used: \\
\hline NHD Plus Hydrography vector data (U.S. Environmental Protection Agency, 2006). \\
\hline
\end{tabular}

\begin{tabular}{l}
\hline \multicolumn{1}{c}{ Attribute: road density } \\
\hline Description: \\
\hline $\begin{array}{l}\text { Sum of the length of roads in kilometers in a watershed (county roads and larger) divided by the watershed area in kilometers squared } \\
\text { (Nagel, 2003). }\end{array}$ \\
\hline Method or process: \\
\hline CalcRdDist.vbs. \\
\hline Unit: \\
\hline Kilometers squared. \\
\hline Source data used: \\
\hline Stratmap Phase 2 road network (Texas Water Development Board, Texas Natural Resources Information System, 2008).
\end{tabular}




\section{Attribute: average elevation}

Description:

Average elevation of the entire watershed.

Method or process:

Zonal_Stats_grd.vbs.

Unit:

Meters.

Source data used:

National Elevation Dataset (U.S. Geological Survey, 2009).

\section{Attribute: minimum elevation}

Description:

Minimum elevation in the watershed.

\section{Method or process:}

Zonal_Stats_grd.vbs.

Unit:

Meters.

Source data used:

National Elevation Dataset DEM (U.S. Geological Survey, 2009).

\begin{tabular}{l}
\hline \multicolumn{1}{c}{ Attribute: maximum elevation } \\
\hline Description: \\
\hline Maximum elevation in the watershed. \\
\hline Method or process: \\
\hline Zonal_Stats_grd.vbs. \\
\hline Unit: \\
\hline Meters. \\
\hline Source data used: \\
\hline National Elevation Dataset DEM (U.S. Geological Survey, 2009).
\end{tabular}

National Elevation Dataset DEM (U.S. Geological Survey, 2009).

\begin{tabular}{l}
\hline Attribute: relief \\
\hline Description: \\
\hline Relief of the entire watershed. \\
\hline Method or process: \\
\hline Query calculation in ArcGIS: maximum elevation - minimum elevation. \\
\hline Unit: \\
\hline Meters. \\
\hline Source data used:
\end{tabular}

National Elevation Dataset DEM (U.S. Geological Survey, 2009). 


\begin{tabular}{l}
\hline \multicolumn{1}{c}{ Attribute: average 30-year precipitation } \\
\hline Description: \\
\hline Average annual precipitation for 1980-2009 for the entire watershed. \\
\hline Method or process: \\
\hline Zonal_Stats_grd.vbs. \\
\hline Unit: \\
\hline MM*100. \\
\hline Source data used: \\
\hline PRISM (Parameter-elevation Regressions on Independent Slopes Model) aggregated datasets (Parameter-elevation Regressions on Indepen- \\
dent Slopes Model (PRISM) Climate Group, 2004). \\
\hline
\end{tabular}

\begin{tabular}{ll}
\hline & Attribute: main channel - 10 percent length \\
\hline Description: &
\end{tabular}

Length of 10 percent of a main channel upstream from a monitoring station.

\section{Method or process:}

MCS_10_85.py.

Unit:

Meters.

\section{Source data used:}

National Elevation Dataset DEM (U.S. Geological Survey, 2009) and National Hydrography Dataset (U.S. Geological Survey, 2011).

\begin{tabular}{l}
\hline \multicolumn{1}{|c}{ Attribute: main channel $\mathbf{- 1 0}$ percent point elevation } \\
\hline Description: \\
\hline Elevation found at a point representing 10 percent of the length of a main channel upstream from a monitoring station. \\
\hline Method or process: \\
\hline MCS_10_85.py. \\
\hline Unit: \\
\hline Meters. \\
\hline Source data used: \\
\hline National Elevation Dataset DEM (U.S. Geological Survey, 2009) and National Hydrography Dataset (U.S. Geological Survey, 2011).
\end{tabular}

\begin{tabular}{l}
$\qquad$ Attribute: main channel - $\mathbf{1 0}$ percent to $\mathbf{8 5}$ percent length \\
\hline Description: \\
\hline $\begin{array}{l}\text { Distance between a point } 10 \text { percent upstream from a main channel from a monitoring station and a point } 85 \text { percent upstream from a main } \\
\text { channel from the same monitoring station. }\end{array}$ \\
\hline Method or process: \\
\hline MCS_10_85.py \\
\hline Unit: \\
\hline Meters. \\
\hline Source data used: \\
\hline National Elevation Dataset DEM (U.S. Geological Survey, 2009) and National Hydrography Dataset (U.S. Geological Survey, 2011).
\end{tabular}




\section{Attribute: main channel - 85 percent length}

\section{Description:}

Length of 85 percent of the main channel upstream from the monitoring station.

Method or process:

MCS_10_85.py.

Unit:

Meters.

\section{Source data used:}

National Elevation Dataset DEM (U.S. Geological Survey, 2009) and National Hydrography Dataset (U.S. Geological Survey, 2011).

\begin{tabular}{ll}
\hline & Attribute: main channel - 85 percent point elevation \\
\hline Description: &
\end{tabular}

Elevation found at a point 85 percent upstream from a main channel from a monitoring station.

\section{Method or process:}

MCS_10_85.py

Unit:

Meters.

\section{Source data used:}

National Elevation Dataset DEM (U.S. Geological Survey, 2009) and National Hydrography Dataset (U.S. Geological Survey, 2011)

\begin{tabular}{ll}
\hline & Attribute: main channel - 10 percent to 85 percent slope \\
\hline Description: &
\end{tabular}

S10-85 = DE10-85/L10-85, in which DE10-85 is the difference in elevation between a point 85 percent upstream from a monitoring station on a main channel and a point 10 percent upstream from a monitoring station divided by the distance between those two points.

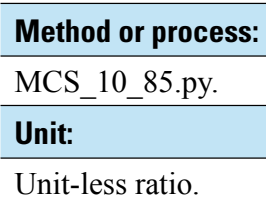

\section{Source data used:}

National Elevation Dataset DEM (U.S. Geological Survey, 2009) and National Hydrography Dataset (U.S. Geological Survey, 2011).

\begin{tabular}{l}
\hline \multicolumn{1}{c}{ Attribute: main channel - pour point elevation } \\
\hline Description: \\
\hline Elevation at a monitoring station along its main channel. \\
\hline Method or process: \\
\hline ArcGIS "Extract Values to Points" tool, using DEM and pour points as input. \\
\hline Unit: \\
\hline Meters. \\
\hline Source data used: \\
\hline National Elevation Dataset DEM (U.S. Geological Survey, 2009) and National Hydrography Dataset (U.S. Geological Survey, 2011). \\
\hline
\end{tabular}




\begin{tabular}{l} 
Attribute: main channel - farthest point elevation \\
\hline Description: \\
\hline Elevation at the farthest point upstream in a main channel from a monitoring station. \\
\hline Method or process: \\
\hline ArcGIS "Extract Values to Points" tool, using DEM and point at end of channel upstream from monitoring station as input. \\
\hline Unit: \\
\hline Meters. \\
\hline Source data used: \\
\hline National Elevation Dataset DEM (U.S. Geological Survey, 2009) and National Hydrography Dataset (U.S. Geological Survey, 2011).
\end{tabular}

\begin{tabular}{|c|}
\hline Attribute: main channel - farthest point length kilometers \\
\hline $\begin{array}{l}\text { Distance measured along the main channel of the watershed from the pour point upstream to the intersection of the main channel and the } \\
\text { HUC- } 08 \text { boundary or the headwaters. }\end{array}$ \\
\hline Method or process: \\
\hline Query calculation in ArcGIS: length between monitoring point and end of channel in kilometers. \\
\hline Kilometers. \\
\hline Source data used: \\
\hline National Elevation Dataset DEM (U.S. Geological Survey, 2009) and National Hydrography Dataset (U.S. Geological Survey, 2011). \\
\hline
\end{tabular}

\begin{tabular}{l}
$\qquad$ Attribute: main channel - farthest point length meters \\
\hline Description: \\
\hline Distance measured along the main channel of the watershed from the pour point upstream to the intersection of the main channel and the \\
HUC-08 boundary or the headwaters. \\
\hline Method or process: \\
\hline Query calculation in ArcGIS: length between monitoring point and end of channel in meters. \\
Unit: \\
\hline Meters. \\
\hline Source data used: \\
\hline National Elevation Dataset DEM (U.S. Geological Survey, 2009) and National Hydrography Dataset (U.S. Geological Survey, 2011). \\
\hline
\end{tabular}

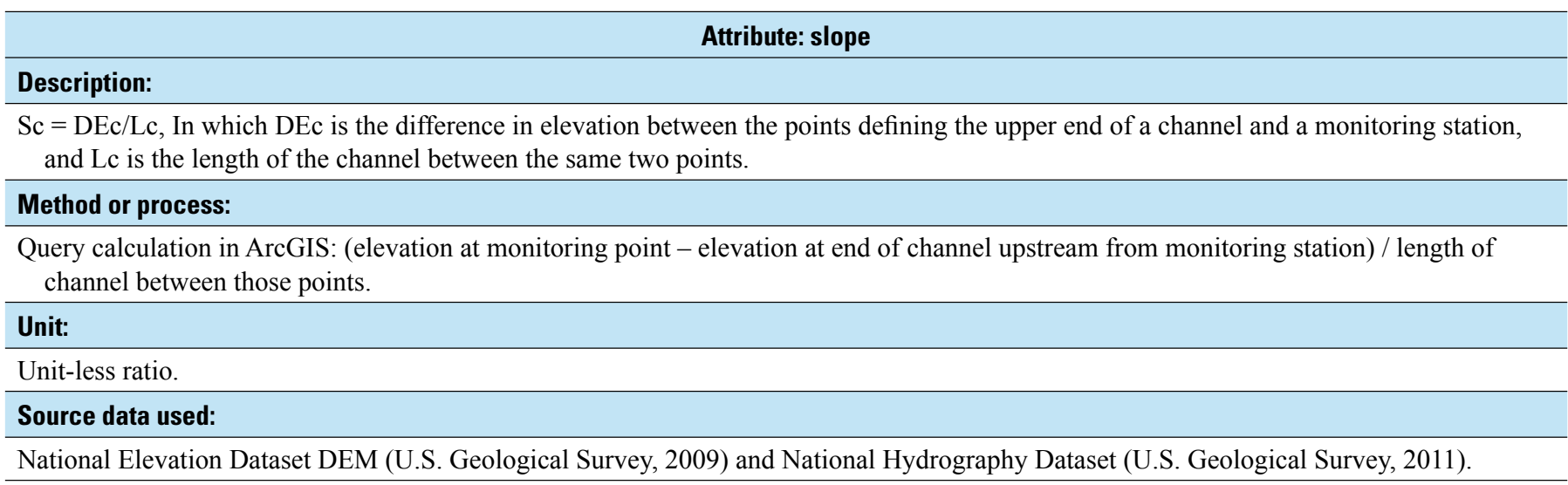




\section{Attribute: main channel - sinuosity ratio}

\section{Description:}

Describes the bending or curving shape of a channel. Actual main channel length divided by straight-line distance. Computed by dividing the channel length by valley length $(\mathrm{CL} / \mathrm{VL})$. It is an approximate measurement of the degree to which a stream channel meanders within its valley (Paybins, 2008).

\section{Method or process:}

Query calculation in ArcGIS: channel length / straight line distance as inputs.

Unit:

Unit-less ratio.

Source data used:

National Elevation Dataset DEM (U.S. Geological Survey, 2009) and National Hydrography Dataset (U.S. Geological Survey, 2011).

\begin{tabular}{l}
$\qquad$ Attribute: main channel slope \\
\hline Description: \\
Rate of elevation change along a main channel. $\mathrm{S}=\mathrm{DE} / \mathrm{L}$, where $\mathrm{DE}$ is the difference in elevation between the end point of the principal \\
flow path and the monitoring station, divided by the hydrologic length of the flow path (L). \\
Method or process: \\
\hline Query calculation in ArcGIS: (elevation at the monitoring station - the elevation at the end of the main channel) / the main channel distance. \\
Unit: \\
\hline Ratio. \\
Source data used: \\
\hline National Elevation Dataset DEM (U.S. Geological Survey, 2009) and National Hydrography Dataset (U.S. Geological Survey, 2011). \\
\hline
\end{tabular}

\begin{tabular}{l}
\hline \multicolumn{1}{c}{ Attribute: main channel slope $-\mathbf{1 k m}$ point } \\
$\begin{array}{l}\text { Description: } \\
\mathrm{S}=\mathrm{DE} / \mathrm{L}, \text { where DE is the difference in elevation between a point } 1 \mathrm{~km} \text { from a monitoring station and the monitoring station point, divided } \\
\text { by the hydrologic length of the flow path }(\mathrm{L}) .\end{array}$ \\
\hline Method or process: \\
\hline MCS1KM.py. \\
\hline Unit: \\
\hline Ratio. \\
\hline Source data used: \\
\hline National Elevation Dataset DEM (U.S. Geological Survey, 2009) and National Hydrography Dataset (U.S. Geological Survey, 2011). \\
\hline
\end{tabular}

\begin{tabular}{l}
\hline \multicolumn{1}{c}{ Attribute: pour point elevation } \\
\hline Description: \\
\hline Elevation found at a monitoring station. \\
\hline Method or process: \\
\hline MCS1KM.py. \\
\hline Unit: \\
\hline Meters. \\
\hline Source data used: \\
\hline National Elevation Dataset DEM (U.S. Geological Survey, 2009) and National Hydrography Dataset (U.S. Geological Survey, 2011). \\
\hline
\end{tabular}




\begin{tabular}{l} 
Attribute: main channel straight line distance \\
\hline Description: \\
\hline Straight-line distance between a monitoring station and the end of the main channel upstream. \\
\hline Method or process: \\
\hline ArcGIS Point to Line tool, with end nodes of main-channel segments (between monitoring station and end of channel) as inputs. \\
\hline Unit: \\
\hline Meters. \\
\hline Source data used: \\
\hline National Elevation Dataset DEM (U.S. Geological Survey, 2009) and National Hydrography Dataset (U.S. Geological Survey, 2011).
\end{tabular}

\begin{tabular}{l}
\hline \multicolumn{1}{c}{ Attribute: land cover - percent open water } \\
\hline Description: \\
\hline Percent Open Water - All areas of open water, generally with less than 25 percent cover of vegetation or soil (U.S. Geological Survey, \\
2008). \\
\hline Method or process: \\
\hline Tabulate Area tool in the Spatial Analyst Extension of ArcGIS10 iterated in Model Builder. \\
\hline Unit: \\
\hline Decimal percent of total area. \\
\hline Source data used: \\
\hline National Land Cover Dataset of 2001 (U.S. Geological Survey, 2008; U.S. Environmental Protection Agency, 2007) \\
\hline
\end{tabular}

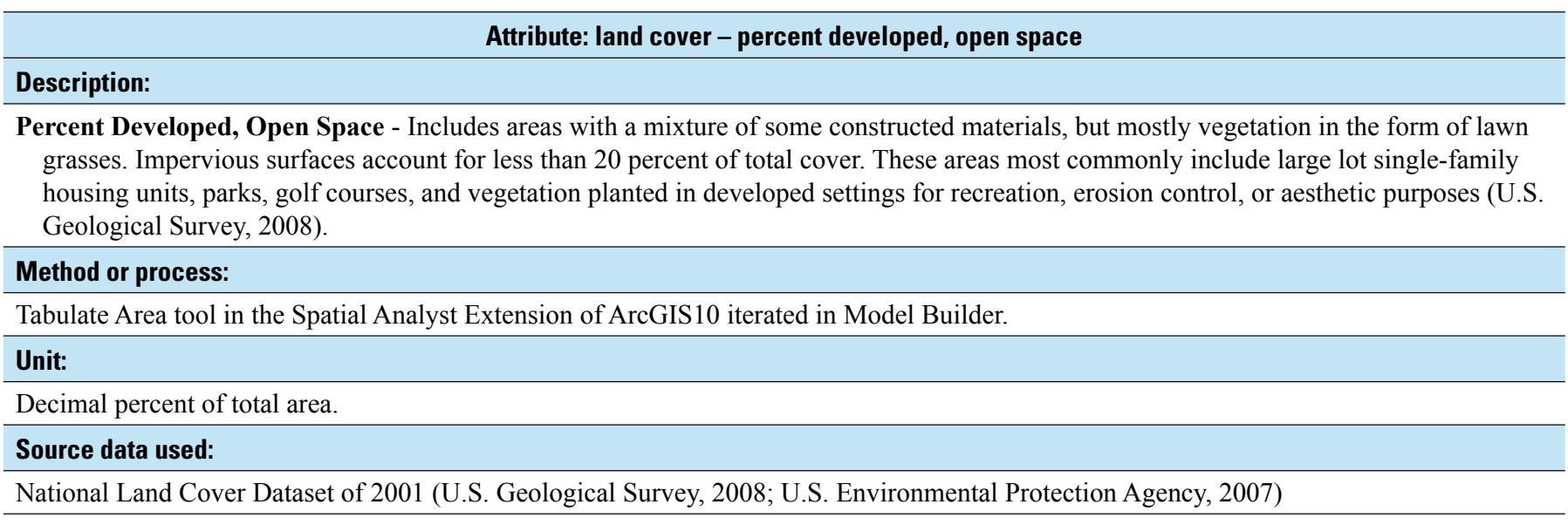

\begin{tabular}{l} 
Attribute: land cover - percent developed, low intensity \\
\hline Description: \\
\hline Percent Developed, Low Intensity - Includes areas with a mixture of constructed materials and vegetation. Impervious surfaces account for \\
20-49 percent of total cover. These areas most commonly include single-family housing units (U.S. Geological Survey, 2008). \\
\hline Method or process: \\
\hline Tabulate Area tool in the Spatial Analyst Extension of ArcGIS10 iterated in Model Builder. \\
\hline Unit: \\
\hline Decimal percent of total area. \\
\hline Source data used: \\
\hline National Land Cover Dataset of 2001 (U.S. Geological Survey, 2008; U.S. Environmental Protection Agency, 2007) \\
\hline
\end{tabular}




\section{Attribute: land cover - percent developed, medium intensity}

\section{Description:}

Percent Developed, Medium Intensity - Includes areas with a mixture of constructed materials and vegetation. Impervious surfaces account for 50-79 percent of the total cover. These areas most commonly include single-family housing units (U.S. Geological Survey, 2008).

\section{Method or process:}

Tabulate Area tool in the Spatial Analyst Extension of ArcGIS10 iterated in Model Builder.

Unit:

Decimal percent of total area.

Source data used:

National Land Cover Dataset of 2001 (U.S. Geological Survey, 2008; U.S. Environmental Protection Agency, 2007)

\begin{tabular}{l} 
Attribute: land cover - percent developed, high intensity \\
\hline Description: \\
Percent Developed, High Intensity - Includes highly developed areas where people reside or work in high numbers. Examples include \\
apartment complexes, row houses, and commercial/industrial. Impervious surfaces account for 80 to 100 percent of the total cover (U.S. \\
Geological Survey, 2008). \\
Method or process:
\end{tabular}

Tabulate Area tool in the Spatial Analyst Extension of ArcGIS10 iterated in Model Builder.

\section{Unit: (What unit is the attribute in?)}

Decimal percent of total area.

\section{Source data used:}

National Land Cover Dataset of 2001 (U.S. Geological Survey, 2008; U.S. Environmental Protection Agency, 2007)

\begin{tabular}{l}
$\qquad$\begin{tabular}{l} 
Attribute: land cover - percent barren land \\
\hline Description:
\end{tabular} \\
$\begin{array}{l}\text { Percent Barren Land (Rock/Sand/Clay) - Barren areas of bedrock, desert pavement, scarps, talus, slides, volcanic material, glacial debris, } \\
\text { sand dunes, strip mines, gravel pits, and other accumulations of earthen material. Generally, vegetation accounts for less than } 15 \text { percent } \\
\text { of total cover (U.S. Geological Survey, 2008). }\end{array}$ \\
\hline Method or process: \\
\hline Tabulate Area tool in the Spatial Analyst Extension of ArcGIS10 iterated in Model Builder. \\
\hline Unit: (What unit is the attribute in?) \\
\hline Decimal percent of total area. \\
\hline Source data used:
\end{tabular}

National Land Cover Dataset of 2001 (U.S. Geological Survey, 2008; U.S. Environmental Protection Agency, 2007)

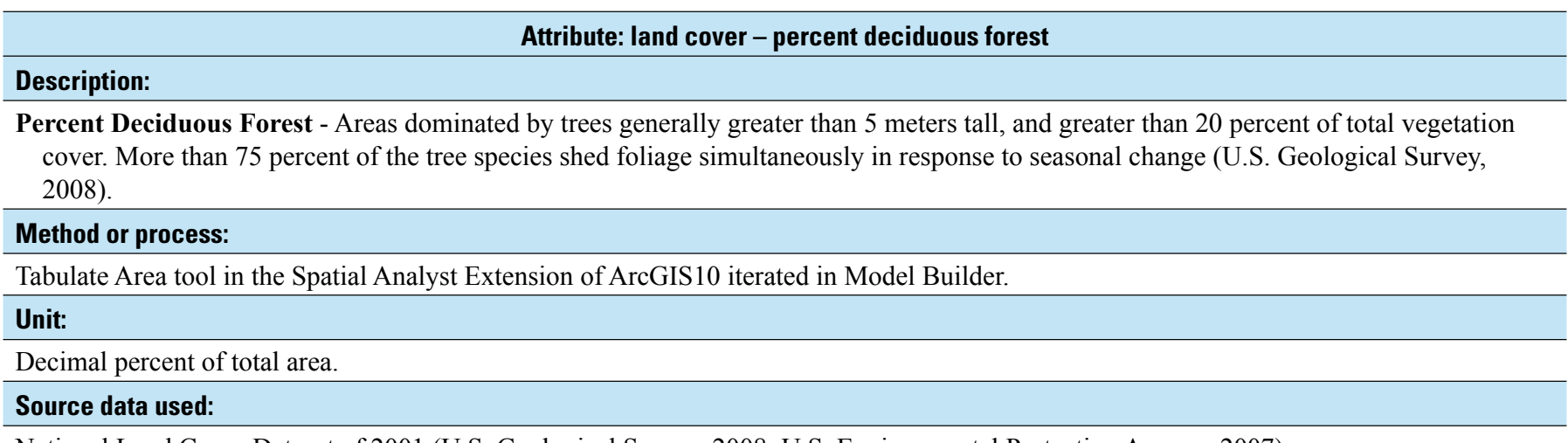

National Land Cover Dataset of 2001 (U.S. Geological Survey, 2008; U.S. Environmental Protection Agency, 2007) 


\begin{tabular}{l}
$\quad$ Attribute: land cover - percent evergreen forest \\
\hline Description: \\
\hline $\begin{array}{l}\text { Percent Evergreen Forest - Areas dominated by trees generally greater than } 5 \text { meters tall, and greater than } 20 \text { percent of total vegetation } \\
\text { cover. More than } 75 \text { percent of the tree species maintain their leaves all year. Canopy is never without green foliage (U.S. Geological } \\
\text { Survey, 2008). }\end{array}$ \\
\hline Method or process: \\
\hline Tabulate Area tool in the Spatial Analyst Extension of ArcGIS10 iterated in Model Builder. \\
\hline Unit: \\
\hline Decimal percent of total area. \\
\hline Source data used: \\
\hline National Land Cover Dataset of 2001 (U.S. Geological Survey, 2008; U.S. Environmental Protection Agency, 2007) \\
\hline
\end{tabular}

\begin{tabular}{l}
$\qquad$ Attribute: Land cover - percent mixed forest \\
\hline Description: \\
\hline $\begin{array}{l}\text { Percent Mixed Forest - Areas dominated by trees generally greater than } 5 \text { meters tall, and greater than } 20 \text { percent of total vegetation cover. } \\
\text { Neither deciduous nor evergreen species are greater than } 75 \text { percent of total tree cover (U.S. Geological Survey, 2008). }\end{array}$ \\
\hline Method or process: \\
\hline Tabulate Area tool in the Spatial Analyst Extension of ArcGIS10 iterated in Model Builder. \\
\hline Unit: \\
\hline Decimal percent of total area. \\
\hline Source data used: \\
\hline National Land Cover Dataset of 2001 (U.S. Geological Survey, 2008; U.S. Environmental Protection Agency, 2007) \\
\hline
\end{tabular}

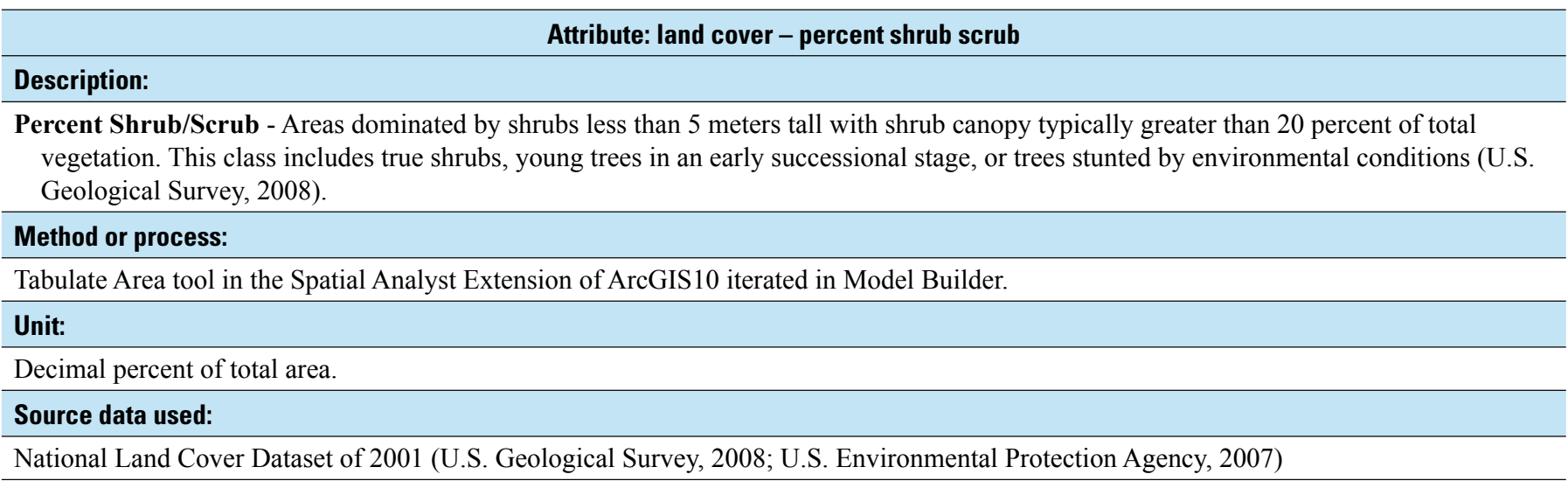

\begin{tabular}{l} 
Attribute: land cover - percent grassland/herbaceous \\
\hline Description: \\
$\begin{array}{l}\text { Percent Grassland/Herbaceous - Areas dominated by grammanoid or herbaceous vegetation, generally greater than } 80 \text { percent of total veg- } \\
\text { etation. These areas are not subject to intensive management such as tilling but can be utilized for grazing (U.S. Geological Survey, 2008). }\end{array}$ \\
\hline Method or process: \\
\hline Tabulate Area tool in the Spatial Analyst Extension of ArcGIS10 iterated in Model Builder. \\
\hline Unit: \\
\hline Decimal percent of total area. \\
\hline Source data used: \\
\hline National Land Cover Dataset of 2001 (U.S. Geological Survey, 2008; U.S. Environmental Protection Agency, 2007) \\
\hline
\end{tabular}




\section{Attribute: land cover - percent pasture/hay}

Description:

Percent Pasture/Hay - Areas of grasses, legumes, or grass-legume mixtures planted for livestock grazing or the production of seed or hay crops, typically on a perennial cycle. Pasture/hay vegetation accounts for greater than 20 percent of total vegetation (U.S. Geological Survey, 2008).

\section{Method or process:}

Tabulate Area tool in the Spatial Analyst Extension of ArcGIS10 iterated in Model Builder.

Unit:

Decimal percent of total area.

Source data used:

National Land Cover Dataset of 2001 (U.S. Geological Survey, 2008; U.S. Environmental Protection Agency, 2007)

\begin{tabular}{l}
$\qquad$ Attribute: land cover - percent cultivated crops \\
\hline Description: \\
Percent Cultivated Crops - Areas used for the production of annual crops, such as corn, soybeans, vegetables, tobacco, and cotton, and also \\
perennial woody crops such as orchards and vineyards. Crop vegetation accounts for greater than 20 percent of total vegetation. This class \\
also includes all land being actively tilled (U.S. Geological Survey, 2008). \\
Method or process:
\end{tabular}

Tabulate Area tool in the Spatial Analyst Extension of ArcGIS10 iterated in Model Builder.

Unit:

Decimal percent of total area.

\section{Source data used:}

National Land Cover Dataset of 2001 (U.S. Geological Survey, 2008; U.S. Environmental Protection Agency, 2007)

\begin{tabular}{l}
$\qquad$ Attribute: land cover - percent woody wetlands \\
\hline Description: \\
\hline $\begin{array}{l}\text { Percent Woody Wetlands - Areas where forest or shrubland vegetation accounts for greater than } 20 \text { percent of vegetative cover and the soil } \\
\text { or substrate is periodically saturated with or covered with water (U.S. Geological Survey, 2008). }\end{array}$ \\
\hline Method or process: \\
\hline Tabulate Area tool in the Spatial Analyst Extension of ArcGIS10 iterated in Model Builder. \\
\hline Unit: \\
\hline Decimal percent of total area. \\
\hline Source data used: \\
\hline National Land Cover; (U.S. Geological Survey, 2008; U.S. Environmental Protection Agency, 2007)
\end{tabular}

National Land Cover ; (U.S. Geological Survey, 2008; U.S. Environmental Protection Agency, 2007)

\begin{tabular}{l}
$\quad$ Attribute: land cover - percent emergent herbaceous wetlands \\
\hline Description: \\
$\begin{array}{l}\text { Percent Emergent Herbaceous Wetlands - Areas where perennial herbaceous vegetation accounts for greater than } 80 \text { percent of vegetative } \\
\text { cover and the soil or substrate is periodically saturated with or covered with water (U.S. Geological Survey, 2008). }\end{array}$ \\
\hline Method or process: \\
\hline Tabulate Area tool in the Spatial Analyst Extension of ArcGIS10 iterated in Model Builder. \\
\hline Unit: \\
\hline Decimal percent of total area. \\
\hline Source data used: \\
\hline National Land Cover Dataset of 2001 (U.S. Geological Survey, 2008; U.S. Environmental Protection Agency, 2007) \\
\hline
\end{tabular}




\begin{tabular}{|c|}
\hline Attribute: land cover - percent no data \\
\hline Description: \\
\hline No land cover data available (U.S. Geological Survey, 2008). \\
\hline Method or process: \\
\hline Tabulate Area tool in the Spatial Analyst Extension of ArcGIS10 iterated in Model Builder. \\
\hline Unit: \\
\hline Decimal percent of total area. \\
\hline Source data used: \\
\hline National Land Cover Dataset of 2001 (U.S. Geological Survey, 2008; U.S. Environmental Protection Agency, 2007) \\
\hline
\end{tabular}

\begin{tabular}{l} 
Attribute: riparian land cover - percent open water \\
\hline Description: \\
\hline $\begin{array}{l}\text { Percent Open Water of riparian area - All areas of open water, generally with less than } 25 \text { percent cover of vegetation or soil (U.S. Geo- } \\
\text { logical Survey, 2008). }\end{array}$ \\
\hline Method or process: \\
\hline Tabulate Area tool in the Spatial Analyst Extension of ArcGIS10 iterated in Model Builder. \\
\hline Unit: \\
\hline Decimal percent of total area. \\
\hline Source data used: \\
\hline National Land Cover Dataset of 2001 (U.S. Geological Survey, 2008; U.S. Environmental Protection Agency, 2007) \\
\hline
\end{tabular}

\begin{tabular}{l}
$\quad$ Attribute: riparian land cover - percent developed, open space \\
\hline Description: \\
\hline $\begin{array}{l}\text { Percent Developed, Open Space of riparian area - Includes areas with a mixture of some constructed materials, but mostly vegetation in } \\
\text { the form of lawn grasses. Impervious surfaces account for less than } 20 \text { percent of total cover. These areas most commonly include large } \\
\text { lot single-family housing units, parks, golf courses, and vegetation planted in developed settings for recreation, erosion control, or aes- } \\
\text { thetic purposes (U.S. Geological Survey, 2008). }\end{array}$ \\
\hline Method or process: \\
\hline Tabulate Area tool in the Spatial Analyst Extension of ArcGIS10 iterated in Model Builder. \\
\hline Unit: \\
\hline Decimal percent of total area. \\
\hline Source data used: \\
\hline National Land Cover Dataset of 2001 (U.S. Geological Survey, 2008; U.S. Environmental Protection Agency, 2007) \\
\hline
\end{tabular}

\begin{tabular}{|c|}
\hline Attribute: riparian land cover - percent developed, low intensity \\
\hline Description: \\
\hline $\begin{array}{l}\text { Percent Developed, Low Intensity of riparian area - Includes areas with a mixture of constructed materials and ve } \\
\text { ous surfaces account for 20-49 percent of total cover. These areas most commonly include single-family housing } u \\
\text { Survey, 2008). }\end{array}$ \\
\hline Method or process: \\
\hline Tabulate Area tool in the Spatial Analyst Extension of ArcGIS10 iterated in Model Builder. \\
\hline Decimal percent of total area. \\
\hline Source data used: \\
\hline National Land Cover Dataset of 2001 (U.S. Geological Survey, 2008; U.S. Environmental Protection Agency, 2007) \\
\hline
\end{tabular}




\section{Attribute: riparian land cover - percent developed, medium intensity}

Description:

Percent Developed, Medium Intensity of riparian area - Includes areas with a mixture of constructed materials and vegetation. Impervious surfaces account for 50-79 percent of the total cover. These areas most commonly include single-family housing units (U.S. Geological Survey, 2008).

\section{Method or process:}

Tabulate Area tool in the Spatial Analyst Extension of ArcGIS10 iterated in Model Builder.

Unit:

Decimal percent of total area.

Source data used:

National Land Cover ; (U.S. Geological Survey, 2008)

\begin{tabular}{ll}
\hline & Attribute: riparian land cover - percent developed, high intensity \\
\hline Description: & \\
\hline
\end{tabular}

Percent Developed, High Intensity of riparian area - Includes highly developed areas where people reside or work in high numbers. Examples include apartment complexes, row houses, and commercial/industrial. Impervious surfaces account for 80 to 100 percent of the total cover (U.S. Geological Survey, 2008).

\section{Method or process:}

Tabulate Area tool in the Spatial Analyst Extension of ArcGIS10 iterated in Model Builder.

Unit:

Decimal percent of total area.

\section{Source data used:}

National Land Cover Dataset of 2001 (U.S. Geological Survey, 2008)

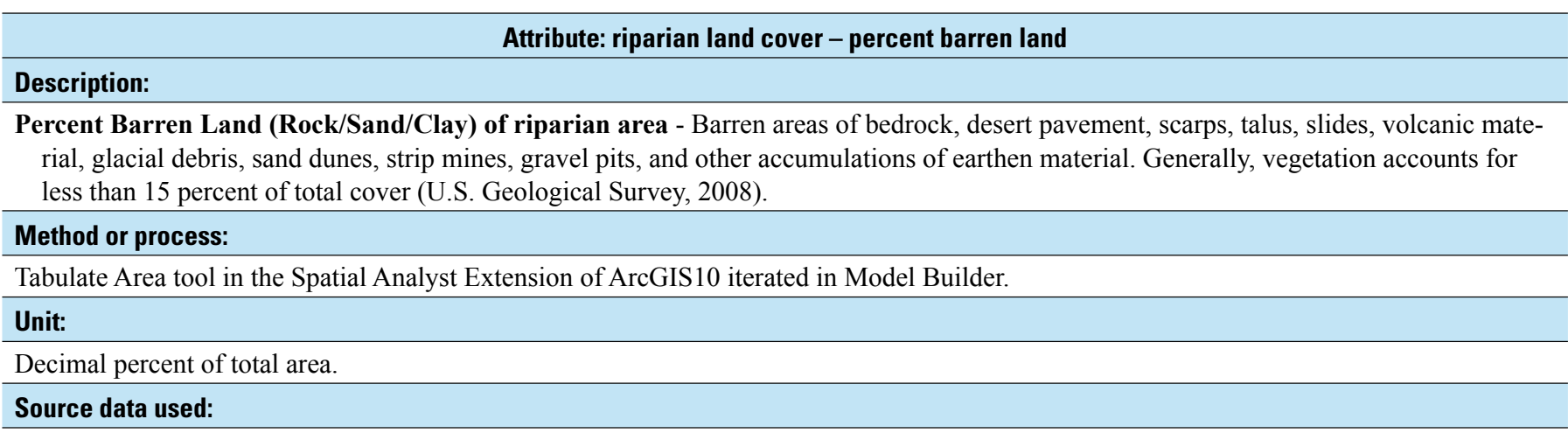

National Land Cover Dataset of 2001 (U.S. Geological Survey, 2008)

\begin{tabular}{l} 
Attribute: riparian land cover - percent deciduous forest \\
\hline Description: \\
\hline $\begin{array}{l}\text { Percent Deciduous Forest of riparian area - Areas dominated by trees generally greater than } 5 \text { meters tall and greater than } 20 \text { percent of } \\
\text { total vegetation cover. More than } 75 \text { percent of the tree species shed foliage simultaneously in response to seasonal change (U.S. Geologi- } \\
\text { cal Survey, 2008). }\end{array}$ \\
\hline Method or process: \\
\hline Tabulate Area tool in the Spatial Analyst Extension of ArcGIS10 iterated in Model Builder. \\
\hline Unit: \\
\hline Decimal percent of total area. \\
\hline Source data used:
\end{tabular}

National Land Cover Dataset of 2001 (U.S. Geological Survey, 2008) 


\section{Attribute: riparian land cover - percent evergreen forest}

\section{Description:}

Percent Evergreen Forest of riparian area - Areas dominated by trees generally greater than 5 meters tall and greater than 20 percent of total vegetation cover. More than 75 percent of the tree species maintain their leaves all year. Canopy is never without green foliage (U.S. Geological Survey, 2008).

\section{Method or process:}

Tabulate Area tool in the Spatial Analyst Extension of ArcGIS10 iterated in Model Builder.

Unit:

Decimal percent of total area.

Source data used:

National Land Cover Dataset of 2001 (U.S. Geological Survey, 2008)

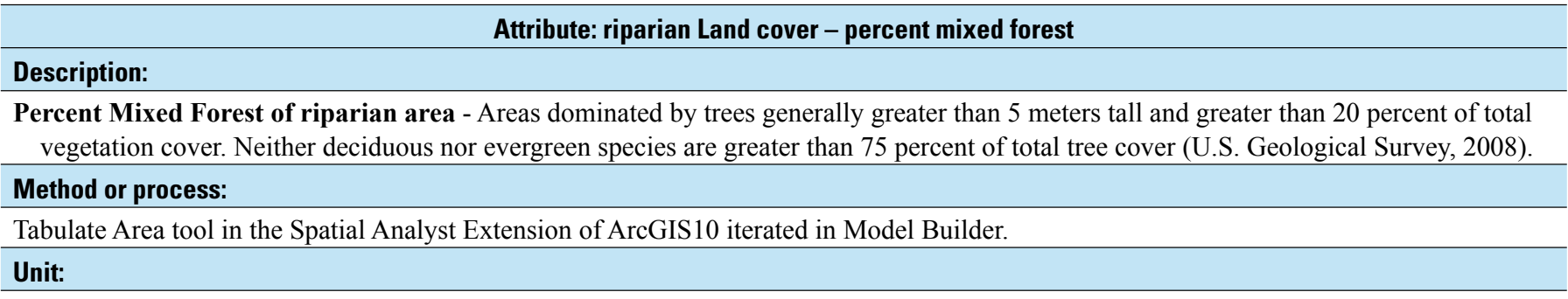

Decimal percent of total area.

Source data used:

National Land Cover Dataset of 2001 (U.S. Geological Survey, 2008)

\begin{tabular}{l}
$\qquad$ Attribute: riparian land cover - percent shrub scrub \\
\hline Description: \\
\hline $\begin{array}{l}\text { Percent Shrub/Scrub of riparian area - Areas dominated by shrubs less than } 5 \text { meters tall with shrub canopy typically greater than } 20 \\
\text { percent of total vegetation. This class includes true shrubs, young trees in an early successional stage, or trees stunted by environmental } \\
\text { conditions (U.S. Geological Survey, 2008). }\end{array}$ \\
\hline Method or process: \\
\hline Tabulate Area tool in the Spatial Analyst Extension of ArcGIS10 iterated in Model Builder. \\
\hline Unit: \\
\hline Decimal percent of total area. \\
\hline Source data used:
\end{tabular}

National Land Cover Dataset of 2001 (U.S. Geological Survey, 2008)

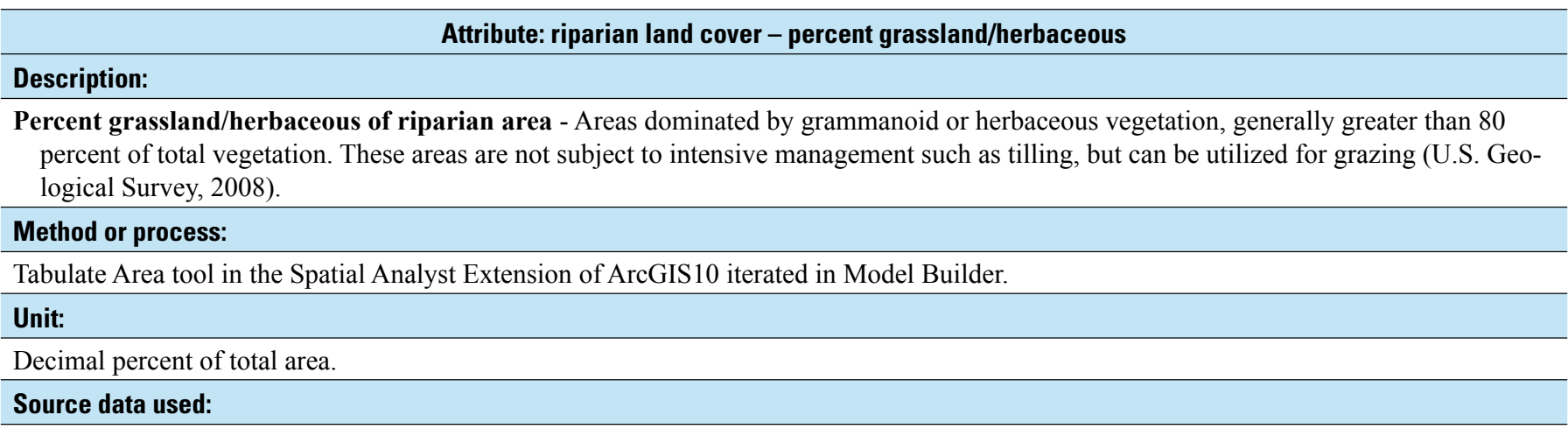

National Land Cover Dataset of 2001 (U.S. Geological Survey, 2008) 


\section{Attribute: riparian land cover - percent pasture/hay}

\section{Description:}

Percent Pasture/Hay of riparian area - Areas of grasses, legumes, or grass-legume mixtures planted for livestock grazing or the production of seed or hay crops, typically on a perennial cycle. Pasture/hay vegetation accounts for greater than 20 percent of total vegetation (U.S. Geological Survey, 2008).

\section{Method or process:}

Tabulate Area tool in the Spatial Analyst Extension of ArcGIS10 iterated in Model Builder.

Unit:

Decimal percent of total area.

Source data used:

National Land Cover Dataset of 2001 (U.S. Geological Survey, 2008)

\section{Attribute: riparian land cover - percent cultivated crops}

\section{Description:}

Percent Cultivated Crops of riparian area - Areas used for the production of annual crops, such as corn, soybeans, vegetables, tobacco, and cotton, and also perennial woody crops such as orchards and vineyards. Crop vegetation accounts for greater than 20 percent of total vegetation. This class also includes all land being actively tilled (U.S. Geological Survey, 2008).

\section{Method or process:}

Tabulate Area tool in the Spatial Analyst Extension of ArcGIS10 iterated in Model Builder.

Unit:

Decimal percent of total area.

Source data used:

National Land Cover Dataset of 2001 (U.S. Geological Survey, 2008)

\section{Attribute: riparian land cover - percent emergent herbaceous wetlands}

\section{Description:}

Percent Emergent Herbaceous Wetlands of riparian area- Areas where perennial herbaceous vegetation accounts for greater than 80 percent of vegetative cover, and the soil or substrate is periodically saturated with or covered with water (U.S. Geological Survey, 2008).

\section{Method or process:}

Tabulate Area tool in the Spatial Analyst Extension of ArcGIS10 iterated in Model Builder.

Unit:

Decimal percent of total area.

Source data used:

National Land Cover Dataset of 2001 (U.S. Geological Survey, 2008) 
Publishing support provided by Lafayette Publishing Service Center

Information regarding water resources in Texas is available at http://tx.usgs.gov/ 



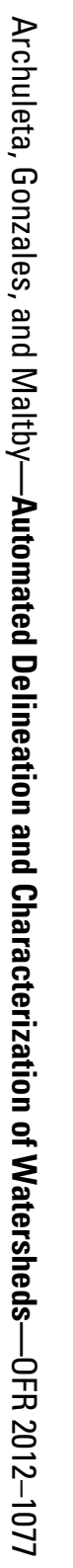

6 Printed on recycled paper 